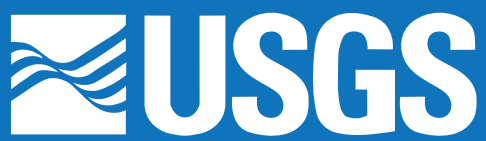

science for a changing world

Prepared in cooperation with the Leech Lake Band of Ojibwe, Department of Resource Management

\title{
Fate and Transport of Petroleum Hydrocarbons in the Subsurface near Cass Lake, Minnesota
}

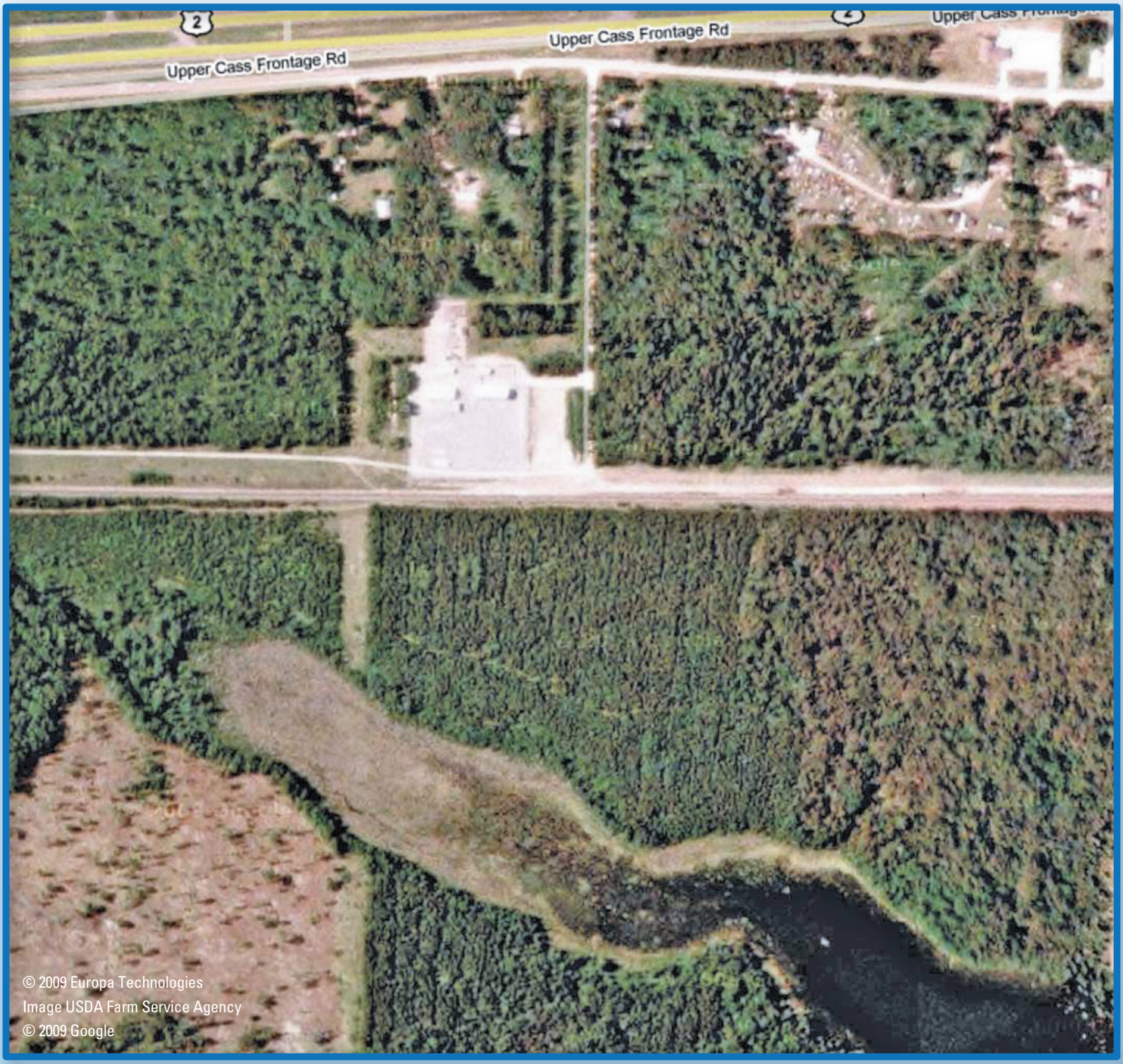

Scientific Investigations Report 2010-5085 
This page left intentionally blank. 


\section{Fate and Transport of Petroleum Hydrocarbons in the Subsurface near Cass Lake, Minnesota}

By Dina M. Drennan, Barbara A. Bekins, Ean Warren, Isabelle M. Cozzarelli, Mary Jo Baedecker, William N. Herkelrath, Geoffrey N. Delin, Robert J. Rosenbauer, and Pamela L. Campbell

Prepared in cooperation with the Leech Lake Band of Ojibwe, Department of Resource Management

Scientific Investigations Report 2010-5085 


\title{
U.S. Department of the Interior \\ KEN SALAZAR, Secretary
}

\author{
U.S. Geological Survey \\ Marcia K. McNutt, Director
}

\section{U.S. Geological Survey, Reston, Virginia: 2010}

This report and any updates to it are available online at:

http://pubs.usgs.gov/sir/2010/5085

For product and ordering information:

World Wide Web: http//www.usgs.gov/pubprod

Telephone: 1-888-ASK-USGS (1-888-275-8747)

For more information on the USGS - the Federal source for science about the Earth, its natural and living resources, natural hazards, and the environment:

World Wide Web: http://www.usgs.gov/

Telephone: 1-888-ASK-USGS (1-888-275-8747)

Any use of trade, product, or firm names in this publication is for descriptive purposes only and does not imply endorsement of the U.S. Government.

Although this report is in the public domain, permission must be secured from the individual copyright owners to reproduce any copyrighted materials contained within this report.

Suggested citation:

Drennan, D.M., Bekins, B.A., Warren, E., Cozzarelli, I.M., Baedecker, M.J., Herkelrath, W.N., Delin, G.N.,

Rosenbauer, R.J., and Campbell, P.L., 2010, Fate and transport of petroleum hydrocarbons in the subsurface near Cass Lake, Minnesota: U.S. Geological Survey Scientific Investigations Report 2010-5085, 33 p.

FRONT COVER

Satellite image of the South Cass Lake Pumping Station and surrounding area. 


\section{Contents}

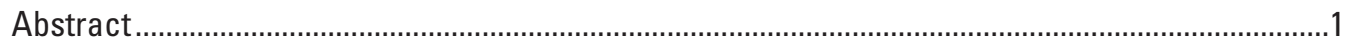

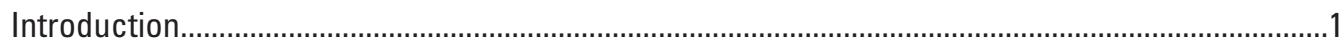

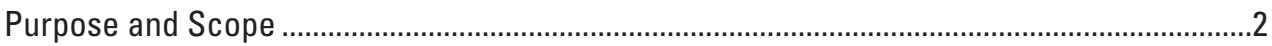

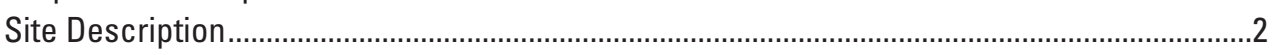

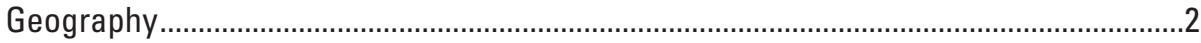

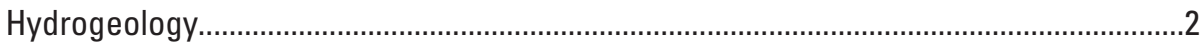

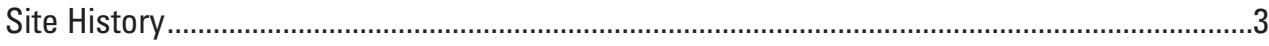

Biodegradation of Petroleum Hydrocarbons ………....................................................

Evidence Used to Demonstrate Biodegradation ...........................................................

Description of the Bemidji Research Site ....................................................................

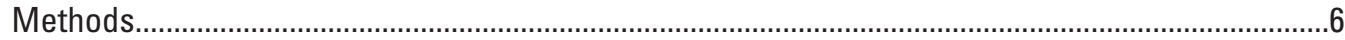

Sample Collection by Push-Probe ....................................................................................

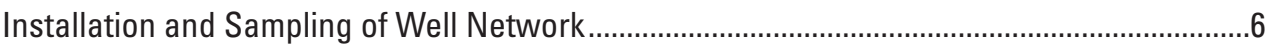

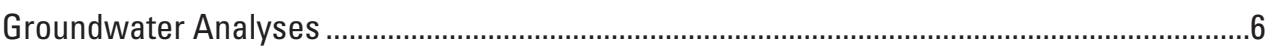

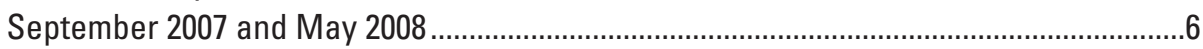

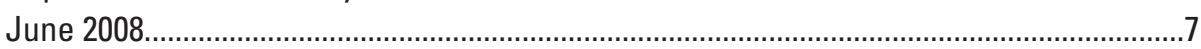

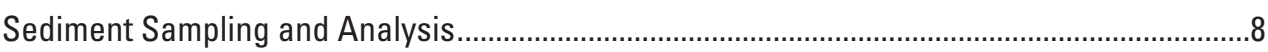

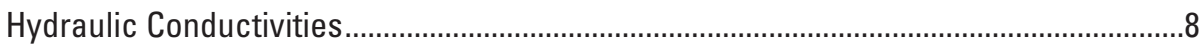

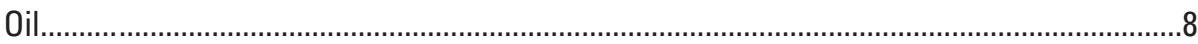

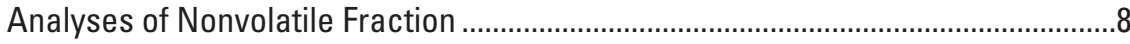

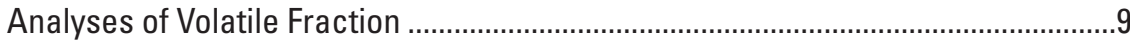

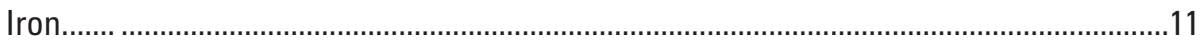

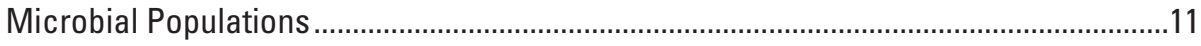

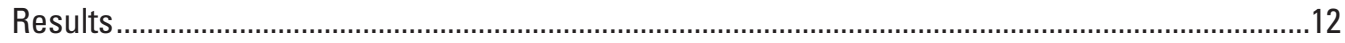

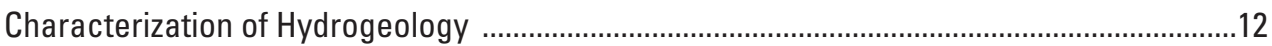

Head Distribution and Flow Directions ..........................................................................12

Hydraulic Conductivities, Discharge Rate, and Flow Velocity ........................................12

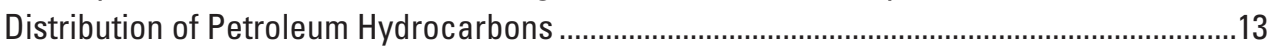

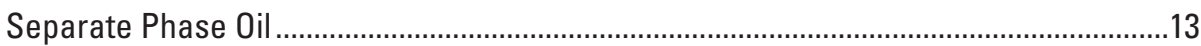

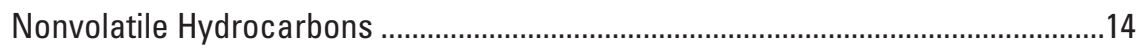

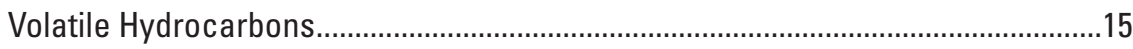

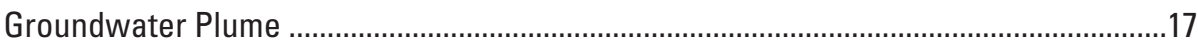

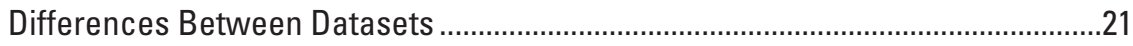

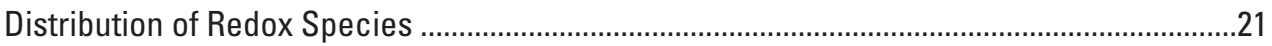

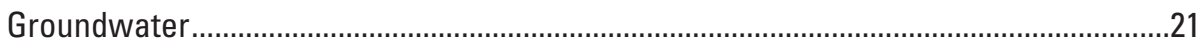

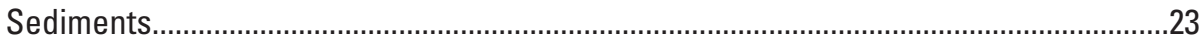

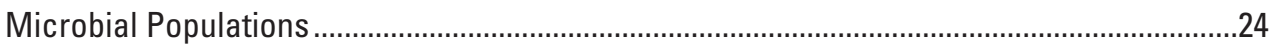

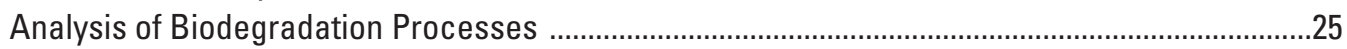

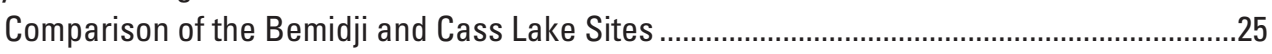

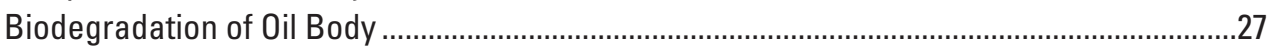

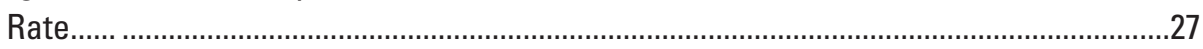

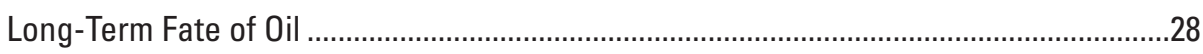

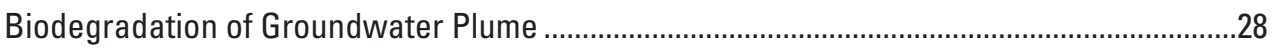

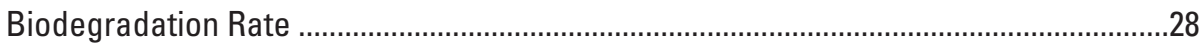

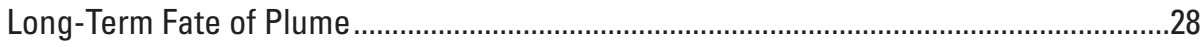

Conclusions

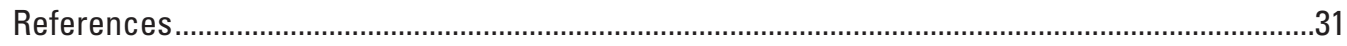




\section{Figures}

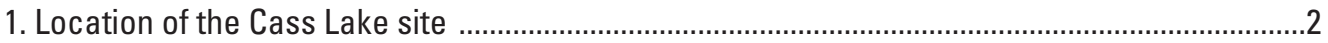

2. Locations of previous monitoring wells and borings at the Cass Lake site .................................

3. Water table elevations $(\mathrm{m})$ beneath the Cass Lake site .......................................................12

4. Saturated thickness $(\mathrm{m})$ of the surficial sand-and-gravel aquifer at the Cass Lake site .........13

5. Frequency distribution of log hydraulic conductivity $(\mathrm{m} / \mathrm{d})$ determined from grain size analyses of 16 samples collected at the Cass Lake site ...................................................14

6. Comparison of $n$-alkanes in oil and sediment samples as determined by gas chromatograph/mass spectrometry

7. Comparison of concentrations of benzene, toluene, ethylbenzene, and xylenes (BTEX); cycloalkanes; methylbenzenes; and methylnaphthalenes $(\mathrm{mg} / \mathrm{g}$ ) in Cass Lake spilled oil, Cass Lake pipeline oil, and oil extracted from sediment ....................................15

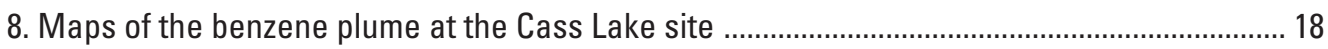

9. Benzene concentrations $(\mu \mathrm{g} / \mathrm{L})$ in the Cass Lake plume ........................................................20

10. Maps of reduced iron $\mathrm{Fe}(\mathrm{II})(\mathrm{mg} / \mathrm{L})$ in the Cass Lake plume ..................................................22

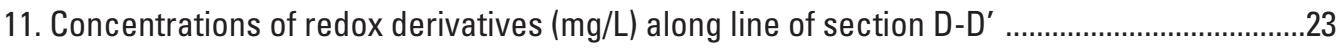

12. Average oxidized iron Fe(III) measured in sediment cores ..................................................23

13. Most probable number (MPN) of four major physiological types of microorganisms along

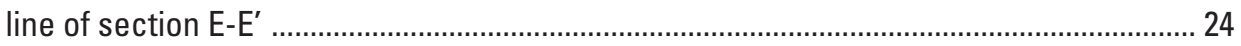

14. Geochemical zones in the unsaturated and saturated hydrologic zones at the Bemidji crude-oil spill site ..........................................................................................................26

15. Conceptual model of the oil spill and plume at the Cass Lake site, showing major

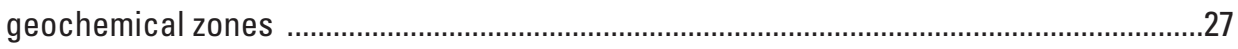

16. Average concentrations (mg/L) of selected constituents at the Cass Lake site versus

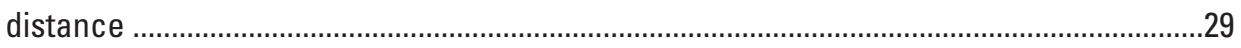

17. Position of oil body and $10-\mu \mathrm{g} / \mathrm{L}$ benzene contour line in the Cass Lake plume .......................30

\section{List of Tables}

1. Biodegradation reactions of benzene under aerobic and anaerobic conditions ..........................5

2. Site identification numbers for wells installed in May 2008 by U.S. Geological Survey ...............7

3. Locations of samples collected for sediment iron and microbial analyses at the

Cass Lake site, 2008 ...............................................................................................

4. Results of grain-size analyses and calculated hydraulic conductivities for core samples

collected at the Cass Lake site ....................................................................................10

5. Selected results of oil analyses: $\delta^{13} \mathrm{C}$ values for oil extracted from sediments at the South Cass Lake Pumping Station ........................................................................................13

6. Results of analyses of oil collected from a South Cass Lake Pumping Station pipeline ............16

7. Values of selected parameters in water from the background well (MW-1) and selected contaminated wells .....................................................................................19

8. Results of iron analyses from core samples collected from the Cass Lake site, 2008 ................25 


\title{
Fate and Transport of Petroleum Hydrocarbons in the Subsurface near Cass Lake, Minnesota
}

\author{
By Dina M. Drennan, Barbara A. Bekins, Ean Warren, Isabelle M. Cozzarelli, Mary Jo Baedecker, William N. \\ Herkelrath, Geoffrey N. Delin, Robert J. Rosenbauer, and Pamela L. Campbell
}

\section{Abstract}

The U.S. Geological Survey (USGS) investigated the natural attenuation of subsurface petroleum hydrocarbons leaked over an unknown number of years from an oil pipeline under the Enbridge Energy Limited Partnership South Cass Lake Pumping Station, in Cass Lake, Minnesota. Three weeks of field work conducted between May 2007 and July 2008 delineated a dissolved plume of aromatic hydrocarbons and characterized the biodegradation processes of the petroleum. Field activities included installing monitoring wells, collecting sediment cores, sampling water from wells, and measuring water-table elevations. Geochemical measurements included concentrations of constituents in both spilled and pipeline oil, dissolved alkylbenzenes and redox constituents, sediment bioavailable iron, and aquifer microbial populations. Groundwater in this area flows eastsoutheast at approximately 26 meters per year. Results from the oil analyses indicate a high degree of biodegradation, characterized by nearly complete absence of $n$-alkanes. Cass Lake oil samples were more degraded than two oil samples collected in 2008 from the similarly contaminated USGS Bemidji, Minnesota, research site 40 kilometers away. Based on 19 ratios developed for comparing oil sources, the conclusion is that the oils at the two sites appear to be from the same hydrocarbon source.

In the Cass Lake groundwater plume, benzene concentrations decrease by three orders of magnitude within 150 meters $(\mathrm{m})$ downgradient from the oil body floating on the water table (between well MW-10 and USGS-4 well nest). The depths of the highest benzene concentrations increase with distance downgradient from the oil, a condition typical of plumes in shallow, unconfined aquifers. Background groundwater, which is nearly saturated with oxygen, becomes almost entirely anaerobic in the plume. As at the Bemidji site, the most important biodegradation processes are anaerobic and dominated by iron reduction. The similarity between the Cass Lake and Bemidji benzene degradation rates, redox conditions, and aquifer material all support a hypothesis that the Cass Lake plume, like the Bemidji plume, is decades old.
As concentrations of alkylbenzenes in the oil decrease over time, the benzene concentrations in the groundwater plume will also decrease and the plume is expected to shrink. The Fox Creek wetland, about $250 \mathrm{~m}$ south of the Cass Lake site, is the nearest receptor to the south.

\section{Introduction}

Crude-oil contamination was detected in the subsurface beneath an oil pipeline pumping station (the Enbridge Energy Limited Partnership South Cass Lake Pumping Station) in Cass Lake, Minnesota (fig. 1) in May 2001 (Natural Resources Engineering Company, 2003). The Leech Lake Band of Ojibwe Department of Resource Management (DRM) is concerned that crude-oil contaminants may threaten water supplies, human health, or the environment by migrating off site to nearby domestic water wells and surface water bodies. To address this concern, USGS did a study in cooperation with Leech Lake Band of Ojibwe, Department of Resource Management. Previous studies on the fate of crude oil in the subsurface in a similar sand-and-gravel aquifer at a long-term research site 20 kilometers $(\mathrm{km})$ northwest of Bemidji, Minnesota, and $40 \mathrm{~km}$ northwest of the Cass Lake site, provide a comprehensive scientific framework within which to evaluate the Cass Lake spill.

Studies at the oil-contaminated Bemidji research site (Baedecker and others, 1993; Eganhouse and others, 1993; Bennett and others, 1993) and other hydrocarbon-contaminated sites nationwide (for example, Rice and others, 1995) show that groundwater contaminants from crude oil and gasoline biodegrade naturally in the subsurface. When the degradation rate is rapid compared to the groundwater velocity, the distance of migration of contaminants away from the relatively stationary oil is limited to less than a few hundred meters. The long-term outlook for contaminant migration depends on the continued ability of subsurface microbial communities to degrade the contaminants. How long a hydrocarbon groundwater contaminant plume will persist depends on the amount of oil in the subsurface and the rate that contaminants are leached from the oil. Degradation rates must be examined individually at each site 
where natural biodegradation may be used to manage groundwater contamination (National Research Council, 2000).

\section{Purpose and Scope}

The purpose of this study is to examine whether natural attenuation can control the spread of the crude-oil contamination from the South Cass Lake Pumping Station (the Cass Lake site). This report describes the important natural attenuation processes of petroleum hydrocarbons in the shallow surficial aquifer below and downgradient of the Cass Lake site. The results extend and supplement data provided by Enbridge Energy and its consultants to assist DRM and Enbridge in their management of the Cass Lake site. The work consisted of three phases: (1) delineation of the plume of dissolved petroleum hydrocarbons in three dimensions, (2) characterization of the redox zones and physiologic types of subsurface microorganisms in the plume, and (3) evaluation of the natural attenuation capacity and sustainability of the biodegradation reactions. The methods, approach, and hypotheses for this study are derived from the knowledge gained from more than 25 years of research at Bemidji and other petroleum-contaminated sites. An important goal of this study is to determine whether degradation rates differ at the two sites (Cass Lake and Bemidji) and, if so, to understand the most important contributing factors.

\section{Site Description}

\section{Geography}

The Cass Lake site (fig. 1A) is located in north-central Minnesota, $2.25 \mathrm{~km}$ west of downtown Cass Lake and within the reservation environment of the Leech Lake Band of Ojibwe. The nearest surface water bodies are Spike Lake, $1 \mathrm{~km}$ south by southwest, and a wetland at the head of Fox Creek, about $250 \mathrm{~m}$ to the south (fig. 1B). There are about a dozen homes or small businesses within $1 \mathrm{~km}$ of the site, primarily to the northwest and northeast, with no homes or businesses within $1 \mathrm{~km}$ to the southwest or southeast. Annual precipitation is approximately 61 centimeters $(\mathrm{cm})$ a year.

\section{Hydrogeology}

The glacial outwash aquifer beneath the Cass Lake site constitutes part of the Bemidji-Bagley outwash plain (Kanivetsky, 1979; Stark and others, 1991). The aquifer consists primarily of moderately well sorted fine to mediumgrained sand and silt with some interbedded gravel. Grey calcareous clay-rich till underlies the aquifer 8 to $14 \mathrm{~m}$

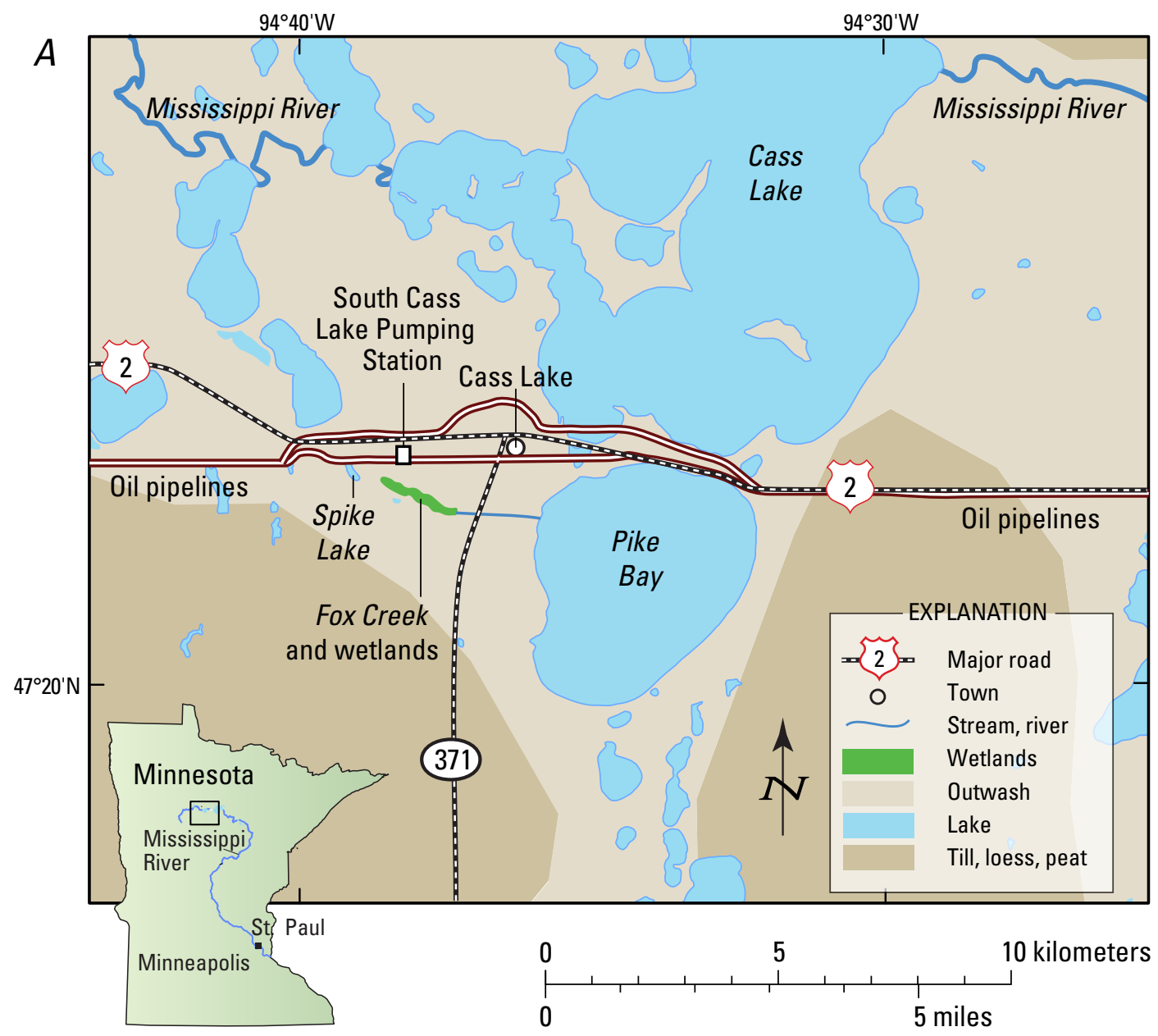

Figure 1. Location of the Cass Lake site. $A$, Surface geology and hydrologic features (modified from Kanivetsky, 1979). $B$, Satellite image of the South Cass Lake Pumping Station and surrounding area. 
below the land surface and crops out at the land surface to the northeast and southwest of the site (fig. 1A). The glacial outwash has a high horizontal hydraulic conductivity compared to the till (Lohman, 1972). Depth to the water table generally varies with topography and is roughly 7 to $9 \mathrm{~m}$ below land surface (Wenck Associates, 2006).

\section{Site History}

Enbridge Energy Limited Partnership (Enbridge), an energy transporter and distributor with extensive crudeoil pipelines in the United States and Canada (http://www. enbridge.com/utility/site-map.php, last accessed April 9,
2010), runs the South Cass Lake Pumping Station. The station was completed in 1971, and the final testing occurred on August 4, 1971 (Karl Beaster, Enbridge Energy, email commun., July 7, 2009). Pumping of oil through the pipeline began shortly thereafter.

In 2001, Enbridge consultants evaluated the shallow groundwater quality at the Cass Lake site to evaluate the geology and aquifer properties, determine if any groundwater contamination occurred, and establish a release-detection warning system. Four monitoring wells were installed in May 2001 (MW-1 to MW-4, fig. 2). The first indication of impacted soil and groundwater was on May 23, 2001, when MW-3 was installed. The Minnesota State Duty Officer was notified, and the Cass Lake site was assigned spill \#54827. On the basis of the monitoring

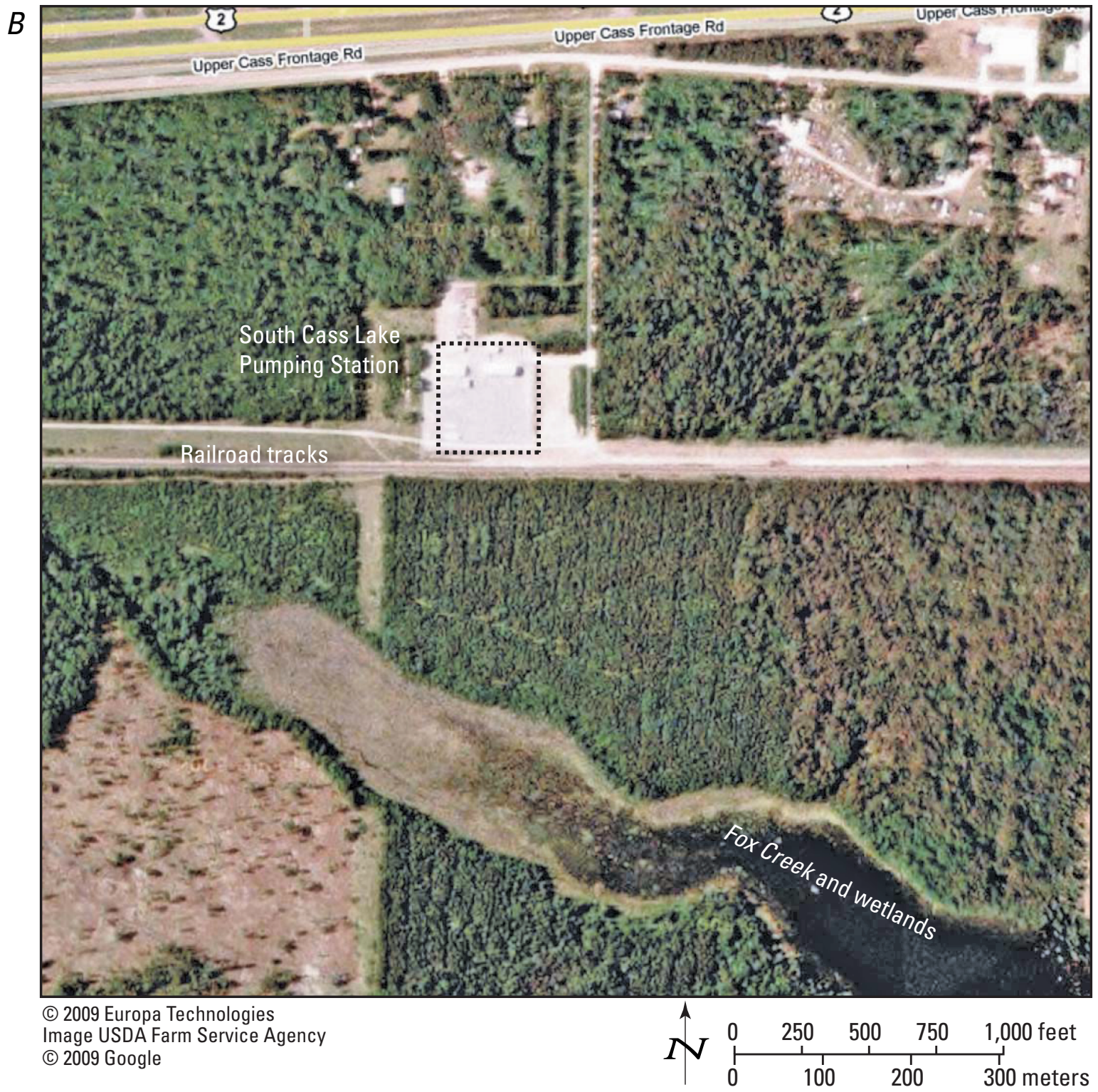

Figure 1.-Continued. 
well data, borings GP-1 through GP-16 were collected using a Geoprobe in September 2001 to define the magnitude and extent of the dissolved and free-phase hydrocarbons.

In February 2002, a weeping flange connecting two pipes was found $23 \mathrm{~m}$ upgradient from well MW-3 (Natural Resources Engineering Company, 2003) and was identified as the location of the original spill site. It was repaired soon after its discovery, but the date that the leak first started is unknown. About 278 cubic meters $\left(\mathrm{m}^{3}\right)$ of contaminated soil were removed in 2002; some impacted soil was left in place to maintain the integrity of the pipeline. A second Geoprobe survey (GP-17 through GP-20, fig. 2) was conducted on August $13-14,2002$, to define the area of offsite contamination.

The extent of the separate-phase oil body shown in figure 2 was established by the two Geoprobe surveys conducted by Natural Resources Engineering Company (2003). The maximum thickness of oil contamination observed in the drill cuttings was $0.61 \mathrm{~m}$. About 182,000 liters (L) of crude oil were estimated to be floating on the water table in 2005 (Wenck Associates, 2005). Kinematic viscosity of the crude oil measured at $10^{\circ} \mathrm{C}$ varied from a low of $23 \times 10^{-6}$ meters squared per second $\left(\mathrm{m}^{2} / \mathrm{s}\right)$ at MW-13 to a high of $421 \times 10^{-6} \mathrm{~m}^{2} / \mathrm{s}$ at MW-5 (Natural
Resources Engineering Company, 2004). Similarly, the density of the crude oil varied from a low of 0.85 grams per cubic centimeter $\left(\mathrm{g} / \mathrm{cm}^{3}\right)$ at MW-13 to a high of $0.938 \mathrm{~g} / \mathrm{cm}^{3}$ at MW-5. Crude oil thickness was measured in the wells 13 times from June 2001 to January 2006, with thicknesses ranging from $2.7 \mathrm{~cm}$ to $49.7 \mathrm{~cm}$ (Wenck Associates, 2006). Crude oil thicknesses were greater than $30 \mathrm{~cm}$ in wells MW-3, MW-5, MW-11, and MW-13 (fig. 2) in January 2006. Current remediation at the Cass Lake site consists of natural attenuation and periodic bailing of oil from the monitoring wells. In 2008 about $1.4 \mathrm{~L}$ were removed from the wells (Natural Resources Engineering Company, 2009).

Initial groundwater quality samples were collected from monitoring wells in June 2001, and the wells have been sampled regularly since 2004 (Natural Resources Engineering Company, 2009). The dissolved plume of benzene was previously estimated to extend to the southeast from the Cass Lake site to beneath the adjacent railroad tracks. The greatest concentrations of dissolved petroleum hydrocarbon constituents (benzene, 6,500 micrograms per liter, $\mu \mathrm{g} / \mathrm{L}$ ) were detected in well MW-5 (closest to the leaking flange) on January 6, 2004 (Wenck Associates, 2006). The greatest concentration of dis-

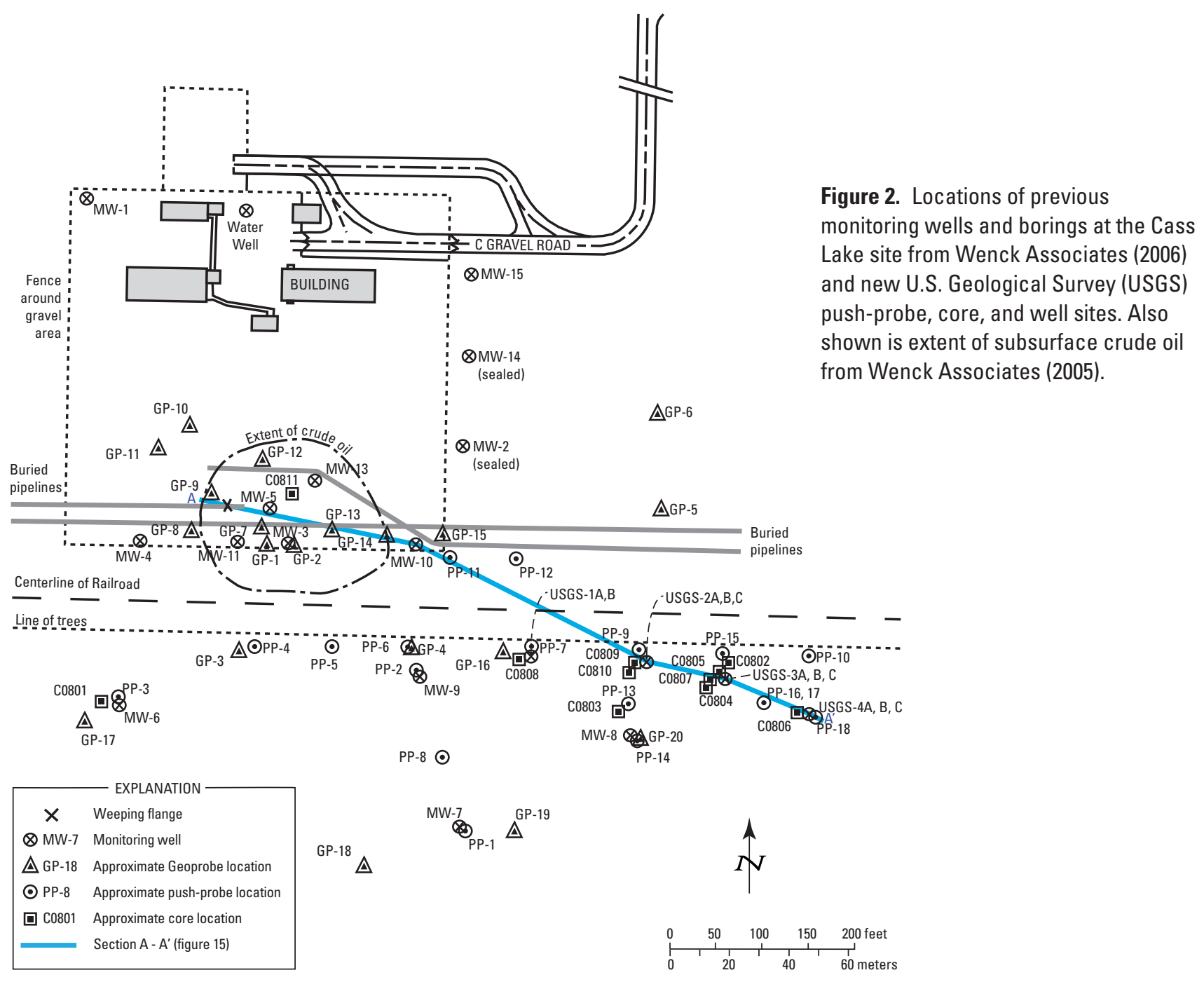


solved benzene offsite, detected on September 25, 2001, in GP-4, was 1,300 $\mu \mathrm{g} / \mathrm{L}$. Periodic detections of benzene were measured in MW-9, downgradient from the oil, with a high concentration of $18 \mu \mathrm{g} / \mathrm{L}$ in April 2005.

Previous work indicated that groundwater movement in the area is generally from northwest to southeast. Slug tests conducted on the monitoring wells to determine the hydraulic conductivity of the aquifer indicated a mean horizontal hydraulic conductivity of approximately 6 meters per day (m/d) (Natural Resources Engineering Company, 2004). The measured water-table gradient was about 0.03 to 0.1 percent. On the basis of these data, the groundwater flow velocity was estimated to be approximately 9 meters per year $(\mathrm{m} / \mathrm{yr})$ to the east-southeast, assuming an effective porosity of 0.25 (Natural Resources Engineering Company, 2004). The dissolved benzene transport velocity was estimated to be about $6.3 \mathrm{~m} / \mathrm{yr}$, based on a benzene retardation factor of 1.59 (Natural Resources Engineering Company, 2004).

\section{Biodegradation of Petroleum Hydrocarbons}

\section{Evidence Used to Demonstrate Biodegradation}

Natural biodegradation transforms petroleum contaminants initially into organic acids and ultimately into final reaction products consisting of carbon dioxide and water. In order to document biodegradation, chemical and microbiological properties of soil and groundwater samples from a contaminated site must be analyzed for contaminants, microorganisms, metabolic reactants and products, and growth nutrients (National Research Council, 1993). As microorganisms consume contaminants, they grow and divide. An increase in microbial population is an indication that natural bioremediation is occurring. When microorganisms metabolize contaminants, they consume oxygen, nitrate, sulfate, and sediment-bound oxidized iron (iron oxyhydroxides) and create characteristic products such as carbon dioxide, ammonia, reduced iron, sulfide, and methane (table 1). Thus, decreased reactant concentrations and the presence of products are evi- dence of biodegradation. Some contaminant mixtures, including crude oil, contain both relatively recalcitrant (degradation resistant) compounds and labile (easily degradable) compounds. An increased ratio of recalcitrant to labile compounds can be another indication of biodegradation. Because microorganisms preferentially consume lighter carbon isotopes, contamination undergoing bioremediation also exhibits a depletion of lighter carbon isotopes (Clark and Fritz, 1997).

\section{Description of the Bemidji Research Site}

The investigation strategy at the Cass Lake crude-oil spill site was based largely on results from research at a site located about $20 \mathrm{~km}$ northwest of Bemidji, Minnesota, and $40 \mathrm{~km}$ from the Cass Lake site. The Bemidji site became contaminated when a pipeline burst on August 20, 1979, dispersing approximately $1,700,000 \mathrm{~L}$ (10,700 barrels) of crude oil onto the land surface. Cleanup efforts immediately after the spill removed about 75 percent of the spilled oil. The remaining 25 percent infiltrated the sand-and-gravel outwash aquifer, forming three subsurface, separate-phase oil bodies. At the largest of these, known as the "north pool," separate-phase oil is present within the sediment pore space from the land surface down through the 6 to $8 \mathrm{~m}$ deep unsaturated zone and to 1 to $2 \mathrm{~m}$ below the water table. A plume of dissolved hydrocarbons in the groundwater extends at least $150 \mathrm{~m}$ downgradient from the source (Cozzarelli and others, 2001). Oil saturations in the sediments (the volume fraction of pore space filled with oil) range from 10 to 20 percent in the unsaturated zone to 30 to 70 percent near the water table (Dillard and others, 1997).

Data from outside the contaminated area indicate that before the Bemidji oil spill the microbial population consisted primarily of aerobic and fermentative bacteria with concentrations of about 100 per gram $(\mathrm{g})$ of sediment. In the contaminated aquifer aerobes, fermenters, iron reducers, and methanogens have increased in concentration up to $1,000,000$ per $g$ of sediment (Essaid and others, 1995). Three microbial physiologic types composed of methanogenic, iron-reducing, and aerobic microorganisms delineate the primary redox reaction zones in the contaminated aquifer. A methanogenic

Table 1. Biodegradation reactions of benzene under aerobic and anaerobic conditions.

\begin{tabular}{|c|c|}
\hline Type of reaction & Balanced chemical equation \\
\hline Aerobic $^{1}$ & $\mathrm{C}_{6} \mathrm{H}_{6}+7.5 \mathrm{O}_{2} \rightarrow 6 \mathrm{CO}_{2}+3 \mathrm{H}_{2} \mathrm{O}$ \\
\hline Nitrate ammonification ${ }^{2}$ & $\mathrm{C}_{6} \mathrm{H}_{6}+3.75 \mathrm{NO}_{3}^{-}+37.5 \mathrm{H}^{+}+0.75 \mathrm{H}_{2} \mathrm{O} \rightarrow 6 \mathrm{CO}_{2}+3.75 \mathrm{NH}_{4}^{+}+30 \mathrm{H}^{+}$ \\
\hline Sulfate reduction ${ }^{1}$ & $\mathrm{C}_{6} \mathrm{H}_{6}+3.75 \mathrm{SO}_{4}^{2-}+7.5 \mathrm{H}^{+} \rightarrow 6 \mathrm{CO}_{2}+3.75 \mathrm{H}_{2} \mathrm{~S}+3 \mathrm{H}_{2} \mathrm{O}$ \\
\hline Iron reduction $^{1}$ & $\mathrm{C}_{6} \mathrm{H}_{6}+30 \mathrm{Fe}(\mathrm{OH})_{3}+60 \mathrm{H}^{+} \rightarrow 6 \mathrm{CO}_{2}+30 \mathrm{Fe}^{2+}+78 \mathrm{H}_{2} \mathrm{O}$ \\
\hline Methanogenesis ${ }^{1}$ & $\mathrm{C}_{6} \mathrm{H}_{6}+4.5 \mathrm{H}_{2} \mathrm{O} \rightarrow 2.25 \mathrm{CO}_{2}+3.75 \mathrm{CH}_{4}$ \\
\hline
\end{tabular}


zone exists near the crude-oil source, where sediment iron has been depleted. Farther from the source, where significant iron is still available, an iron-reducing zone is well developed, with elevated concentrations of iron-reducers relative to the source. Beyond the iron-reducing zone, an aerobic zone is present. Degradation of the oil by reduction of sulfate and nitrate is not significant at the Bemidji site because these chemical species have low concentrations in the groundwater.

\section{Methods}

To delineate the groundwater contaminant plume, a low-cost push-probe was devised to obtain groundwater samples that were then analyzed in the field. The results of the push-probe survey provided data to determine the placement of monitoring-well installations along the centerline of the plume. The push-probe results also guided locations for soil cores used to determine the microbial populations and sediment iron oxyhydroxide concentrations in the aquifer.

\section{Sample Collection by Push-Probe}

In September 2007, groundwater samples were collected at the Cass Lake site using a push-probe tool that was advanced into the ground at 14 locations (fig. 2). The first three locations (PP-1 to PP-3) were sampled using a small-diameter downhole bladder pump (Amos and Blowes, 2008). To improve sample recovery a modified push-probe sampling procedure, termed "peristaltic bailing" (Herkelrath and others, 2008), was developed and successfully employed at the next 11 locations (PP-4 to PP-14). The peristaltic bailing equipment consisted of a Solinst Canada drive-point piezometer attached to the bottom of a 2-cm-diameter stainless-steel pipe with a $15-\mathrm{cm}$ screen. The pipe was manually pounded into the ground using a length of pilot drill rod and a jack hammer. At each water sampling depth, 0.6-cm Teflon tubing was lowered to the bottom of the screen and a peristaltic pump was used to draw water into the tubing. Because all of the sampling depths were below the peristaltic lift depth of about $7.6 \mathrm{~m}$, the Teflon tubing needed to be raised about 2 to $3 \mathrm{~m}$ in order to bring the water to the surface. Sampling at each location continued at target spacings of 20 to $50 \mathrm{~cm}$ until the till was encountered. The depth to till was noted at each site. A total of 49 water samples were obtained at varying depths below the water table. A second round of push-probe sampling was carried out in May 2008. In order to allow drill rig access to find the leading edge of the plume, a path was cut into the forest along a line extending downgradient from the location where the highest benzene, toluene, ethylbenzene, and xylenes (BTEX) concentrations were detected. The push-probe was advanced at four locations (PP-15 to PP-18), and a total of 19 groundwater samples were obtained using the peristaltic bailing method.

Saturated thickness of the sand-and-gravel aquifer was determined by creating grids by triangulation with linear interpolation in Surfer (Golden Software, Golden, Colo., version 9.7.543) of water-table and till elevations and subtracting.

\section{Installation and Sampling of Well Network}

In May 2008, nests of groundwater monitoring wells were installed in the forested area beyond (south of) the railroad right of way (fig. 2). On the basis of the push-probe work, four well locations were chosen along the main transect of the plume with two to three different screen depths at each location. The wells are constructed of 5-cm PVC with $0.3-\mathrm{m}$ screens. Altogether 11 monitoring wells labeled "USGS" were installed (fig. 2): one well nest of two wells (USGS-1A and $-1 \mathrm{~B}$ ) and three well nests of three wells each (USGS-2A, $-2 \mathrm{~B}$, and $-2 \mathrm{C}$; $-3 \mathrm{~A},-3 \mathrm{~B}$, and $-3 \mathrm{C}$; and $-4 \mathrm{~A},-4 \mathrm{~B}$, and $-4 \mathrm{C})$. The depths of the screens and other location data are given in table 2. All 11 USGS wells and 4 of the existing monitoring wells (MW-6, MW-8, MW-9, and MW-10) were sampled in June 2008.

A mini-typhoon pump was used for collecting waterquality parameters from the wells, including $\mathrm{pH}$, temperature, and specific conductivity. The pump screen for the minityphoon pump was approximately $0.3 \mathrm{~m}$ from the bottom of the well. Once these parameters were taken, the mini-typhoon pump was replaced by a Grundfos pump with Teflon tubing to sample for volatile organic carbon, dissolved oxygen, ammonium, major cations, major anions, dissolved methane, dissolved ferrous iron, alkalinity, and nonvolatile organic carbon. At least three well-casing volumes were pumped through the Grundfos pump before water samples were collected. The Grundfos pump screen was approximately 0.46 $\mathrm{m}$ from the bottom of the well.

\section{Groundwater Analyses}

\section{September 2007 and May 2008}

During the screening phase of this study, water samples were analyzed for BTEX and reduced iron in the field. Samples for BTEX analysis were collected without headspace in 40- or 125-milliliter ( $\mathrm{mL}$ ) brown glass bottles, depending on the expected concentrations. Estimates of BTEX concentrations were obtained in the field using a SRI 8610C gas chromatograph (GC) with the flame ionization detector (FID), a 1.0-mL fixed-loop injection, internal air compressor, and a Restek MXT-1 capillary column. A 5-cubic-centimeter gas bubble (ultra pure helium) was created in each sample bottle using a syringe. The sample was equilibrated by shaking for at least 45 minutes ( $\mathrm{min}$ ) at ambient temperature. The headspace gas was injected in the GC. Gas concentrations were converted to water concentration using a calibration curve based on headspace measurements on BTEX standard solutions prepared in the field. 
Dissolved, reduced iron concentrations in water samples were measured in the field by filtering the sample, adding ferrozine solution (following the methods of Gibbs, 1979), and then reading the absorbance with a GENESYS 6 UV-Vis spectrophotometer at 562 nanometers $(\mathrm{nm})$. Concentrations were calculated from a calibration curve based on ferrous ammonium sulfate standards.

\section{June 2008}

Samples collected in June 2008 were analyzed for volatile organic carbon compounds by the U.S. Geological Survey (USGS) National Water Quality Laboratory (NWQL) in Denver, Colo. (http://nwql.usgs.gov/nwql.shtml, last accessed April 9, 2010) using heated purge and trap, gas chromatography, and mass spectrometry. Analyses for other geochemical indicators of BTEX degradation processes were performed in the field and at the USGS laboratories in Reston, Va.

Specific conductance, $\mathrm{pH}$, and downhole temperature of groundwater were determined in the field using a YSI multimeter (model 682-C-M) after parameters had stabilized.
Dissolved oxygen (DO) was measured in the field using CHEMets® Kits (CHEMetrics Inc., Calverton, Va.). Dissolved oxygen is typically determined in the field using spectrophotometric techniques or dissolved oxygen sensors. Low concentrations of dissolved oxygen cannot be accurately measured with a dissolved oxygen sensor because of difficulties calibrating at zero dissolved oxygen (Baedecker and Cozzarelli, 1992; Radtke and others, 1998). In lowoxygen waters, spectrophotometric techniques are preferred, and in those wells with lower dissolved oxygen levels a spectrophotometric technique was employed. Samples for DO measurements must be collected in a manner to eliminate aeration during pumping. For this reason positive displacement pumps were used and gas-impermeable high-density plastic tubing. Wells were purged and samples were collected in a manner to eliminate aeration of the water in the well or the sample. The measurements were collected in triplicate, and the lowest value measured was reported.

Ammonium concentrations were determined in the field on samples using an Ammonia Vacu-vials® Kit and CHEMetrics V2000 photometers. Ferrous iron concentrations were determined in the field on samples that were filtered in line

Table 2. Site identification numbers, latitude (lat.), longitude (long.), measuring point elevations, surface elevations, screen elevations, and water table elevations for wells installed in May 2008 by U.S. Geological Survey.

[Elevations are in meters. The water table elevations were taken in November 2009.]

\begin{tabular}{|c|c|c|c|c|c|c|c|c|}
\hline Well name & $\begin{array}{l}\text { Site identifica- } \\
\text { tion number }\end{array}$ & Lat. & Long. & $\begin{array}{c}\text { Measuring } \\
\text { point } \\
\text { elevation }\end{array}$ & $\begin{array}{l}\text { Surface } \\
\text { elevation }\end{array}$ & $\begin{array}{c}\text { Elevation, } \\
\text { top of } \\
\text { screen }\end{array}$ & $\begin{array}{c}\text { Elevation, } \\
\text { bottom of } \\
\text { screen }\end{array}$ & $\begin{array}{c}\text { Water table } \\
\text { elevation }\end{array}$ \\
\hline USGS-1A & $\begin{array}{r}47223709 \\
4381201\end{array}$ & 47.3772 & -94.6367 & 408.92 & 407.99 & 399.76 & 399.51 & 400.16 \\
\hline USGS-1B & $\begin{array}{l}47223709 \\
4381202\end{array}$ & 47.3772 & -94.6367 & 409.17 & 407.95 & 399.06 & 398.75 & \\
\hline USGS-2A & $\begin{array}{r}47223709 \\
4381001\end{array}$ & 47.3772 & -94.6362 & 409.15 & 408.20 & 399.70 & 399.39 & 400.05 \\
\hline USGS-2B & $\begin{array}{r}47223709 \\
4381002\end{array}$ & 47.3772 & -94.6362 & 409.15 & 408.25 & 399.14 & 398.84 & \\
\hline USGS-2C & $\begin{array}{r}47223709 \\
4381003\end{array}$ & 47.3772 & -94.6362 & 409.16 & 408.11 & 398.38 & 398.14 & \\
\hline USGS-3A & $\begin{array}{r}47223709 \\
4380901\end{array}$ & 47.3771 & -94.6358 & 408.82 & 407.90 & 399.71 & 399.41 & 400.12 \\
\hline USGS-3B & $\begin{array}{r}47223709 \\
4380902\end{array}$ & 47.3771 & -94.6358 & 408.83 & 407.83 & 399.08 & 398.78 & \\
\hline USGS-3C & $\begin{array}{r}47223709 \\
4380903\end{array}$ & 47.3771 & -94.6358 & 408.71 & 407.82 & 397.21 & 396.90 & \\
\hline USGS-4A & $\begin{array}{r}47223609 \\
4380701\end{array}$ & 47.3770 & -94.6355 & 408.32 & 407.68 & 399.71 & 399.42 & 400.11 \\
\hline USGS-4B & $\begin{array}{r}47223609 \\
4380702\end{array}$ & 47.3770 & -94.6355 & 408.54 & 407.65 & 399.04 & 398.74 & \\
\hline USGS-4C & $\begin{array}{r}47223609 \\
4380703\end{array}$ & 47.3770 & -94.6355 & 408.64 & 407.71 & 397.29 & 396.99 & \\
\hline
\end{tabular}


Fate and Transport of Petroleum Hydrocarbons in the Subsurface near Cass Lake, Minnesota

through a 0.2-micrometer $(\mu \mathrm{m})$ Nuclepore ${ }^{\mathrm{TM}}$ filter. Samples were immediately treated in the field with reagents specified by the colorimetric ferrozine technique and analyzed on site using a GENESYS 6 UV-Vis spectrophotometer as described previously for the push-probe sample analyses. Anion samples (including nitrate and sulfate) were filtered in line through a $0.20-\mu \mathrm{m}$ Nuclepore $^{\mathrm{TM}}$ filter into plastic bottles and analyzed by ion chromatography using a Dionex 120 . Nitrate and sulfate detection limits were both 0.5 milligrams per liter $(\mathrm{mg} / \mathrm{L})$. Cation samples were filtered through $0.10-\mu \mathrm{m}$ Nuclepore ${ }^{\mathrm{TM}}$ filters into acid-washed plastic bottles, preserved to $\mathrm{pH} 2$ with nitric acid, and analyzed by inductively coupled plasma mass spectrometry. Alkalinity samples were filtered through a $0.20-\mu \mathrm{m}$ Nuclepore ${ }^{\mathrm{TM}}$ filter into glass bottles and analyzed in the laboratory with a Radiometer (Copenhagen, Denmark) TIM 900 automatic titrator.

Samples for the analysis of the nonvolatile component of dissolved organic carbon (DOC) were filtered through 0.20- $\mu \mathrm{m}$ Supor® filters into baked glass bottles, preserved with hydrochloric acid to a $\mathrm{pH}$ of $<2$, and analyzed using a Shimadzu TOC Vcsn analyzer (Shimadzu Corporation). Methane samples were collected in Glaspak syringes that were connected directly to the sample-pump outlet following the method of Baedecker and Cozzarelli (1992). Methane samples were analyzed using a 5890 Series II HP Gas Chromatograph split/splitless inlet FID with a fused silica capillary column.

\section{Sediment Sampling and Analysis}

Eleven soil cores (C0801-C0811) were collected for grain-size determinations, sediment iron, and microbial analyses. The core locations are shown in figure 2, and table 3 lists the samples collected from each core. Ten cores were collected in June 2008 from outside the fenced area enclosing the pumping station. The eleventh core was collected in July 2008 from inside the fenced area, where separate-phase oil is floating on the water table. Cores were collected by drilling with a hollow-stem auger to the top of the desired coring interval, followed by driving of a piston core barrel beneath the augers to the desired depth. The bottom $10 \mathrm{~cm}$ of the core was frozen in place to prevent loss of fluids during core extraction following the method of Murphy and Herkelrath (1996).

\section{Hydraulic Conductivities}

Grain-size analyses were done on 16 sediment samples (table 4). Each sample was dried, weighed, and separated by grain sizes of $>2$ millimeters (mm), $500 \mu \mathrm{m}$ to $2 \mathrm{~mm}, 106 \mu \mathrm{m}$ to $500 \mu \mathrm{m}, 63 \mu \mathrm{m}$ to $106 \mu \mathrm{m}$, and $<63 \mu \mathrm{m}$. Horizontal hydraulic conductivities were estimated from the grain-size data using the method of Hazen (1892):

$$
K=1000(0.7+0.03 T)\left(D_{10}\right)^{2}
$$

where $K$ is hydraulic conductivity $(\mathrm{m} / \mathrm{d}), T$ is temperature $\left({ }^{\circ} \mathrm{C}\right)$, and $D_{10}$ is the grain diameter $(\mathrm{mm})$ for which 10 percent of the soil is finer. For these samples, the temperature was assumed to be $10^{\circ} \mathrm{C}$.

Past research on a primarily sand-and-gravel glacial outwash aquifer in Cape Cod, Mass., which is very similar to that of the Cass Lake site, confirmed that hydraulic conductivities determined by the Hazen method closely matched those measured with a permeameter on aquifer core samples. In the range of measured values from 0.01 to 0.1 centimeters per second, the hydraulic conductivities estimated from grain-size analysis showed no significant difference from the permeameter results. Furthermore, hydraulic conductivities determined in the aquifer by borehole flowmeter were similar to those measured with the permeameter (Wolf and others, 1991).

Oil

For this study, one core from the oil body was collected in July 2008. The core was located $4.6 \mathrm{~m}$ from MW-13 and $7.6 \mathrm{~m}$ from MW-5 on a line between the two (C0811, fig. 2). The top of the core was at $6.95 \mathrm{~m}$ below land surface, and the core extended to $8.47 \mathrm{~m}$. From visual inspection, oil was present in this core over an interval of $1.03 \mathrm{~m}$. Two sediment samples were preserved for oil analyses: one from above the water table and the second below the water table (sample intervals were 70 to $82 \mathrm{~cm}$ and 108 to $111 \mathrm{~cm}$ below the top of the core, respectively). In addition, two other samples of Cass Lake oil were analyzed: one bailed from MW-3 in September 2007 and one collected from the pipeline in July 2008. Results from the analyses of the Cass Lake samples were compared to analyses of oil extracted from two sediment samples collected in July 2008 from the Bemidji research site (Bemidji Core B0801 interval 22 to $36 \mathrm{~cm}$, located above the water table, and Bemidji Core B0802 interval 10 to $13 \mathrm{~cm}$, located below the water table) and to an archived oil sample collected from the Bemidji pipeline in 1984.

\section{Analyses of Nonvolatile Fraction}

Sediment samples for oil analysis were extracted and analyzed using the method described in Hostettler and others (2007). Ten g of sediment were added to a 50-mL glass beaker. Extractions with dichloromethane (DCM) were performed using successive solvent rinse volumes of 20,15 , and $10 \mathrm{~mL}$. For each extraction, several $\mathrm{g}$ of sodium sulfate were added to the beaker containing the sediment/DCM slurry. The extracts were filtered through a champagne funnel containing a small plug of precombusted glass wool. The extracts were collected into a 50-mL pear-shaped flask and blown down to near-dryness with nitrogen.

The extract was dissolved into $5 \mathrm{~mL}$ of hexane for column fractionation. The two whole oil samples were weighed (25 to 50 milligram, $\mathrm{mg}$ ) directly into a $5-\mathrm{mL}$ centrifuge tube, and DCM was added to the sample, making the final volume $5 \mathrm{~mL}$. The sediment oil and whole oil were added directly to columns containing $2.5 \mathrm{~g}$ activated alumina (40/60 mesh), $2.5 \mathrm{~g}$ silica gel 62 (6-200 mesh, 150 angstroms), and $5.0 \mathrm{~g}$ silica 
Table 3. Locations of samples collected for sediment iron and microbial analyses at the Cass Lake site on June 20-23, 2008, and July 18, 2008.

[Locations of cores C0801 through C0811 shown in figure 2. Depths are in meters (m) and centimeters $(\mathrm{cm})$.]

\begin{tabular}{|c|c|c|c|c|c|}
\hline \multirow[b]{2}{*}{ Core } & \multirow[b]{2}{*}{$\begin{array}{l}\text { General } \\
\text { Iocation }\end{array}$} & \multirow[b]{2}{*}{$\begin{array}{l}\text { Depth } \\
\text { to top of } \\
\text { core, m }\end{array}$} & \multicolumn{3}{|c|}{ Sampling depth in core, cm } \\
\hline & & & $\begin{array}{l}\text { All MPN' }{ }^{1} \\
\text { except iron } \\
\text { reducers }\end{array}$ & $\begin{array}{c}\text { Iron } \\
\text { reducer } \\
\text { MPN }^{1}\end{array}$ & $\begin{array}{l}\text { Sediment for } \\
\text { iron extrac- } \\
\text { tion }\end{array}$ \\
\hline \multirow[t]{2}{*}{$\mathrm{C} 0801$} & MW-6 & 7.79 & 35 & 35 & $35-70$ \\
\hline & & & 70 & 70 & \\
\hline \multirow[t]{3}{*}{$\mathrm{C} 0802$} & PP-15 & 8.32 & 50 & & $50-60$ \\
\hline & & & 100 & & $60-70$ \\
\hline & & & & & $100-114$ \\
\hline $\mathrm{C} 0803$ & PP-13 & 8.18 & 30 & 30 & $11-25$ \\
\hline \multirow[t]{2}{*}{$\mathrm{C} 0804$} & USGS-3 & 7.85 & 20 & & $30-70$ \\
\hline & & & 70 & 70 & \\
\hline $\mathrm{C} 0805$ & USGS-3 & 9.98 & 60 & & $30-60$ \\
\hline \multirow[t]{2}{*}{$\mathrm{C} 0806$} & USGS-4 & 8.99 & 50 & & $0-40$ \\
\hline & & & 90 & & $80-90$ \\
\hline C0807 & USGS-3 & 8.85 & 50 & 50 & $50-80$ \\
\hline $\mathrm{C} 0808$ & USGS-1 & 7.78 & 30 & 30 & $20-30$ \\
\hline C0809 & USGS-2 & 9.29 & 40 & 40 & $50-80$ \\
\hline \multirow[t]{2}{*}{ C0810 } & USGS-2 & 8.41 & 30 & 30 & $30-40$ \\
\hline & & & 90 & & $70-90$ \\
\hline \multirow[t]{2}{*}{$\mathrm{C} 0811$} & Between & 6.95 & 54 & 54 & $91-101$ \\
\hline & $\begin{array}{l}\text { MW-5 and } \\
\text { MW-13 }\end{array}$ & & 108 & 108 & \\
\hline
\end{tabular}

${ }^{1}$ Most Probable Number analyses

gel 923 (100-200 mesh), which were used to fractionate the extract into the F1 fraction eluted with hexane and the F2 fraction eluted with 30-percent DCM in hexane (volume for volume). The F1 fraction contained the aliphatic and branched hydrocarbons and cyclohexanes, whereas the F2 fraction contained the parent and alkylated polycyclic aromatic hydrocarbons. Analyses of the fractions were carried out on a HP 6890 GC equipped with a mass-selective detector. The GC was fitted with a 30-m DB-5 capillary column. The oven temperature was programmed from $60^{\circ} \mathrm{C}$ to $310^{\circ} \mathrm{C}$.

\section{Analyses of Volatile Fraction}

Two oil samples were analyzed for volatile hydrocarbons (VHC). One sample was collected from oil residing in well MW-3 collected in 2007, and the other sample was provided by Lakewood Pipeline Company in 2008 as representative of the oil carried in the pipeline. The samples were stored in a freezer, brought to room temperature and gently shaken before removing a 1-mL sample. A known volume of an internal standard solution consisting of a mixture of perdeuterated compounds was added to the 1-mL sample, which was then mixed on a Vortex mixer before analysis by solid phase microextraction-gas chromatography/ mass spectrometry (SPME-GC/MS). The following perdeuterated compounds were added as internal standards: d-benzene, d-toluene, d-ethylbenzene, d- $m$-xylene, d- $o$-xylene, d-1,3,5-trimethylbenzene, d-naphthalene, d-hexane, d-nonane, and d-dodecane.

In addition to the two oil samples, oil-contaminated sediment from core C0811 (table 3) at $91 \mathrm{~cm}$ below the top of the core was extracted and analyzed for comparison to the oil at well MW-3. The soil core was obtained in 2008 in the most contaminated part of the aquifer about $17 \mathrm{~m}$ north of MW-3 (fig. 2). A 1-g sediment sample was extracted with $1.7 \mathrm{~g}$ dichloromethane (DCM) in a 4-mL vial by sonication for $30 \mathrm{~min}$. An aliquot of the deuterate standards was added before sonication, and a subsample of DCM was analyzed by solid phase microextraction using the method as described for the oils. 
Table 4. Results of grain-size analyses and calculated hydraulic conductivities for core samples collected at the Cass Lake site.

[Dry weights in sediment and total weights are in grams (g). All grain sizes (in micrometers, $\mu \mathrm{m}$, and millimeters, $\mathrm{mm}$ ) are displayed as percent of dry weight. $D_{10}$ (millimeters, mm) represents the diameter of grain size for which $10 \%$ of the soil is finer. Hydraulic conductivities $(K)$ are in meters per day $(\mathrm{m} / \mathrm{d})$.

\begin{tabular}{|c|c|c|c|c|c|c|c|c|c|c|}
\hline $\begin{array}{c}\text { Core/ } \\
\text { Distance, }{ }^{1} \mathrm{~cm}\end{array}$ & $\begin{array}{l}\text { Dry weight } \\
\text { sediment, g }\end{array}$ & $\begin{array}{l}\text { Coarse sand } \\
\text { to gravel } \\
>2 \mathrm{~mm}\end{array}$ & $\begin{array}{l}\text { Medium sand } \\
500 \mu \mathrm{m}-2 \mathrm{~mm}\end{array}$ & $\begin{array}{l}\text { Fine sand } \\
106-500 \mu \mathrm{m}\end{array}$ & $\begin{array}{c}\text { Silt } \\
63-106 \mu \mathrm{m}\end{array}$ & $\begin{array}{l}\text { Silt and clay } \\
\quad<63 \mu \mathrm{m}\end{array}$ & $\begin{array}{c}\text { Total } \\
\text { weight, } \mathrm{g}\end{array}$ & $\begin{array}{l}\% \text { Loss of } \\
\text { sediment }\end{array}$ & $D_{10^{\prime}}, \mathrm{mm}$ & $K, \mathrm{~m} / \mathrm{d}$ \\
\hline C0801/35-70 & 23.93 & 48.02 & 40.87 & 9.03 & 0.48 & 0.87 & 23.75 & 0.74 & 0.36 & 130.98 \\
\hline C0801/60-70 & 23.27 & 12.85 & 30.51 & 40.35 & 7.86 & 8.04 & 23.18 & 0.39 & 0.07 & 5.25 \\
\hline C0802/60-70 & 25.02 & 38.65 & 38.29 & 19.82 & 1.06 & 1.57 & 24.87 & 0.60 & 0.23 & 54.98 \\
\hline C0802/100-114 & 19.22 & 0.90 & 54.21 & 43.96 & 0.21 & 0.19 & 19.12 & 0.52 & 0.21 & 45.97 \\
\hline C0804/30-70 & 26.29 & 61.39 & 27.39 & 8.37 & 1.05 & 1.67 & 26.26 & 0.13 & 0.35 & 122.87 \\
\hline C0804/60-70 & 22.04 & 35.95 & 49.55 & 11.68 & 1.27 & 1.50 & 22.03 & 0.05 & 0.25 & 64.96 \\
\hline C0806/0-40 & 25.35 & 36.52 & 51.14 & 11.18 & 2.92 & 0.52 & 25.93 & $--^{2}$ & 0.28 & 80.28 \\
\hline C0806/80-90 & 23.00 & 3.94 & 49.39 & 42.35 & 1.51 & 2.17 & 22.85 & 0.64 & 0.15 & 21.68 \\
\hline C0807/50-80 & 25.84 & 45.39 & 47.52 & 6.48 & 0.26 & 0.21 & 25.81 & 0.13 & 0.46 & 215.73 \\
\hline C0808/20-30 & 32.70 & 42.60 & 43.79 & 11.59 & 0.80 & 1.02 & 32.64 & 0.20 & 0.31 & 94.04 \\
\hline C0810/30-40 & 26.15 & 30.57 & 35.76 & 19.40 & 6.47 & 7.58 & 26.09 & 0.22 & 0.08 & 6.92 \\
\hline C0810/70-90 & 22.13 & 22.46 & 59.38 & 15.45 & 0.82 & 1.56 & 22.06 & 0.33 & 0.22 & 50.61 \\
\hline C0811/60-70 & 23.29 & 0.38 & 46.25 & 49.74 & 0.36 & 0.19 & 22.57 & 3.08 & 0.20 & 39.27 \\
\hline C0811/91-101 & 26.78 & 3.63 & 71.66 & 21.22 & 0.46 & 0.41 & 26.08 & 2.62 & 0.23 & 52.58 \\
\hline
\end{tabular}

${ }^{1}$ Distance from top of core (centimeter, cm, intervals). See table 3 for depth to top of cores

${ }^{2}$ Total weight is greater than dry weight. 
Using a syringe, a 10-microliter $(\mu \mathrm{L})$ sample of oil or $20-\mu \mathrm{L}$ sample of DCM was placed in a 4-mL vial with $500 \mathrm{mg}$ of vacuum pump oil and mixed on a Vortex mixer for $1 \mathrm{~min}$. A 100- $\mu \mathrm{m}$ polydimethylsiloxane-coated fiber was exposed to the headspace of the vial for $10 \mathrm{~min}$. The fiber was then inserted into the heated inlet $\left(250^{\circ} \mathrm{C}\right)$ of an Agilent $6890 \mathrm{GC}$ coupled with a 5973 mass spectrometer. The GC was equipped with a $30-\mathrm{m}$ DB- $5 \mathrm{~ms}$ column $(0.25 \mathrm{~mm}$ ID and $0.25 \mu \mathrm{m}$ thick coating) and programmed as follows: hold at $-50^{\circ} \mathrm{C}$ for $2 \mathrm{~min}$, $20^{\circ} \mathrm{C}$ per min to $20^{\circ} \mathrm{C}$, hold $5 \mathrm{~min}, 5^{\circ} \mathrm{C}$ per min to $100^{\circ} \mathrm{C}$, $25^{\circ} \mathrm{C}$ per min to $225^{\circ} \mathrm{C}$, and hold for $1 \mathrm{~min}$.

The concentrations of compounds reported were calculated using the internal perdeuterated standards with the following exceptions. The normal hydrocarbons $\mathrm{C}_{7}$ and $\mathrm{C}_{8}$ were calculated assuming a linear response of the perdeuterated internal standards $\mathrm{C}_{6}$ and $\mathrm{C}_{9}$, respectively; $\mathrm{C}_{10}$ and $\mathrm{C}_{11}$ were based on $\mathrm{C}_{9}$ and $\mathrm{C}_{12}$, respectively. Cyclohexane, methylcyclohexane, ethylcyclohexane, the tetramethylbenzenes, and the methylnaphthalenes were quantified using the nearest perdeuterated internal standard based on retention time and structure and a relative response factor. The relative response factor was calculated from an external standard that contained these compounds and the perdeuterated standards listed above. This corrected for differences in response of the ion current for different compounds. These concentrations should be considered less accurate than the concentrations calculated using internal standards.

\section{Iron}

Analyses of sediment-iron content were performed on a total of 17 sediment samples from the Cass Lake site. Cores collected for sediment-iron analyses were left in the polycarbonate core liners, cut into sections, frozen in the field, and shipped frozen to the lab. In the lab, the cores were thawed and, while cold, placed in an anoxic glove bag. About 50 grams (g) of sediment from each core was placed in a centrifuge tube and mixed with a spatula, in order to homogenize the sample. Pebbles greater than $1 \mathrm{~cm}$ in diameter were removed. Sediment samples of about $2.5 \mathrm{~g}$ were placed in serum bottles and $20 \mathrm{~mL}$ of 0.5-molar (M) hydrochloric acid was added to each bottle; all samples were prepared in triplicate. The serum bottles were sealed with rubber stoppers, crimped, and wrapped with aluminum foil while in the glove bag.

Outside the glove bag, the bottles were gently shaken for 24 hours. About $5 \mathrm{~mL}$ of acid was removed with a syringe and filtered through a $0.2-\mu \mathrm{m}$ Supor ${ }^{\circledR}$ syringe tip filter. The sample was immediately analyzed using the ferrozine colorimetric method (modified from the method of Gibbs, 1979). In a cuvette, a 100- $\mu \mathrm{L}$ sample was added to $3 \mathrm{~mL}$ of ferrozine solution (2.0-millimolar (mM) ferrozine solution made in 0.05-M HEPES buffer and adjusted to $\mathrm{pH}$ 6.5). The color complex was read at 562 nanometer (nm) wavelength for reduced iron and compared to standards that were prepared using the same volumes as for the samples. A $10-\mathrm{mM}$ standard iron solution was made from ferrous ammonium sulfate (Sigma-Ultra), and dilutions were made from $0.005 \mathrm{mM}$ to $2 \mathrm{mM}$. Total iron was measured on the filtered samples on a Perkin-Elmer 4300DV optical emission spectrometer; oxidized iron was determined by difference.

A separate sediment sample of about $25 \mathrm{~g}$ was placed in an aluminum pan and weighed. This sample was then dried at $60^{\circ} \mathrm{C}$ for 24 hours, and the sediment was again weighed to determine the percent water in the sediment for calculation of the iron concentrations in millimoles per kilogram $(\mathrm{mmol} / \mathrm{kg})$ dry weight sediment. The dried sediment was then sieved into 5 fractions through sieves of the same sizes as for grain-size analysis.

\section{Microbial Populations}

Sediment samples for microbial analyses were collected using sterile techniques at one or two locations within each core (table 3). Concentrations of aerobic heterotrophic, anaerobic heterotrophic, iron-reducing, sulfate-reducing, and methanogenic microorganisms were measured in sediment samples by a Most Probable Number (MPN) analysis (Warren and others, 2006). MPN analysis is a statistical method in which samples are diluted by factors of 10 and then used to inoculate selective media that encourage the growth of specific physiologic types of microorganisms. The concentrations in the original sample are determined from the growth patterns of the inoculated media. Five replicate analyses provide an estimate of the 95-percent confidence intervals. The upper end of the 95-percent confidence interval corresponds to about three times the MPN and the lower end to one-third of the MPN (Meyall and Meyall, 1970). On a $\log _{10}$ scale this is approximately plus or minus one-half log unit.

Microorganisms attached to sediments must be suspended in a solution before dilution. The method for the sample preparation and the preparation and analysis of different media can be found in Warren and others (2006). Briefly, microorganisms were extracted from sediments using a surfactant solution and sonication. Extracted cell suspensions were diluted in series, by orders of magnitude into prereduced anaerobic mineralsalts solutions. Aliquots of the dilutions were used to inoculate six different media designed to promote growth of the target physiological groups of microorganisms.

Microorganisms capable of aerobic, heterotrophic growth were enumerated by counting test tubes containing Standard Methods Broth with visible growth after incubation. Microorganisms capable of anaerobic, heterotrophic growth or fermentation were enumerated using anaerobically prepared Schaedler's Broth with turbid growth or clumps of particulates after incubation. Iron-reducing microorganisms were enumerated using the method found in Warren and others (2006) with goethite (Lovley and Phillips, 1986) as the oxidized iron source. Media for sulfatereducing and methanogenic microorganisms consisted of anaerobic mineral-salts media with acetate as well as sulfate or hydrogen, respectively, as electron acceptors. The activity of sulfate-reducing bacteria was determined from the presence of sulfide using lead acetate paper. Similarly, the presence of methane was used to indicate methanogen activity (Warren and others, 2006). 


\section{Results}

\section{Characterization of Hydrogeology}

\section{Head Distribution and Flow Directions}

The water table is relatively flat at the Cass Lake site, with groundwater flow primarily to the east or east-southeast (fig. 3). Starting at MW-13, in the oil body source zone, the direction of flow is east-southeast toward well nest USGS-4. The head gradient at the water table along the flow line from MW-13 to USGS-4 is 0.00057 meter per meter $(\mathrm{m} / \mathrm{m})$, which falls in the previously estimated range of 0.0003 to $0.001 \mathrm{~m} / \mathrm{m}$ (Natural Resources Engineering Company, 2004).

Geologic information gathered during the 2007-2008 push-probe work indicates that the saturated thickness of the aquifer and depth to the glacial till decrease to the south and increase to the east and northeast from the Cass Lake site. The contour plot in figure 4 shows that the saturated thickness of the sand and gravel exceeds $6 \mathrm{~m}$ at MW-1 but thins southward to only about $1 \mathrm{~m}$ at MW-9 and USGS-1. The thinning of the saturated thickness causes the groundwater flow in the sandand-gravel aquifer beneath the Cass Lake site to be diverted eastward from the southeast regional flow direction.

\section{Hydraulic Conductivities, Discharge Rate, and Flow Velocity}

The grain-size data from 16 samples indicate that most of the sediments are poorly sorted (table 4), with grain sizes ranging from gravel to sand and silt, with a few samples containing cobble-size particles. The dominant grain-size fraction in the samples is coarse sand. The horizontal hydraulic conductivities estimated with the Hazen method ranged from 5 to 216 meters per day (m/d), with a geometric mean value of $47 \mathrm{~m} / \mathrm{d}$ (fig. 5).

Combining the head gradient and mean hydraulic conductivity values gives an estimated specific discharge rate of $9.8 \mathrm{~m} / \mathrm{yr}$. Converting this to a pore-water velocity using a porosity of 0.38 (Essaid and others, 1995) results in a velocity of $26 \mathrm{~m} / \mathrm{yr}$. The previous estimate of $9 \mathrm{~m} / \mathrm{yr}$ was based on an assumed effective porosity of 0.25 , a measured gradient of

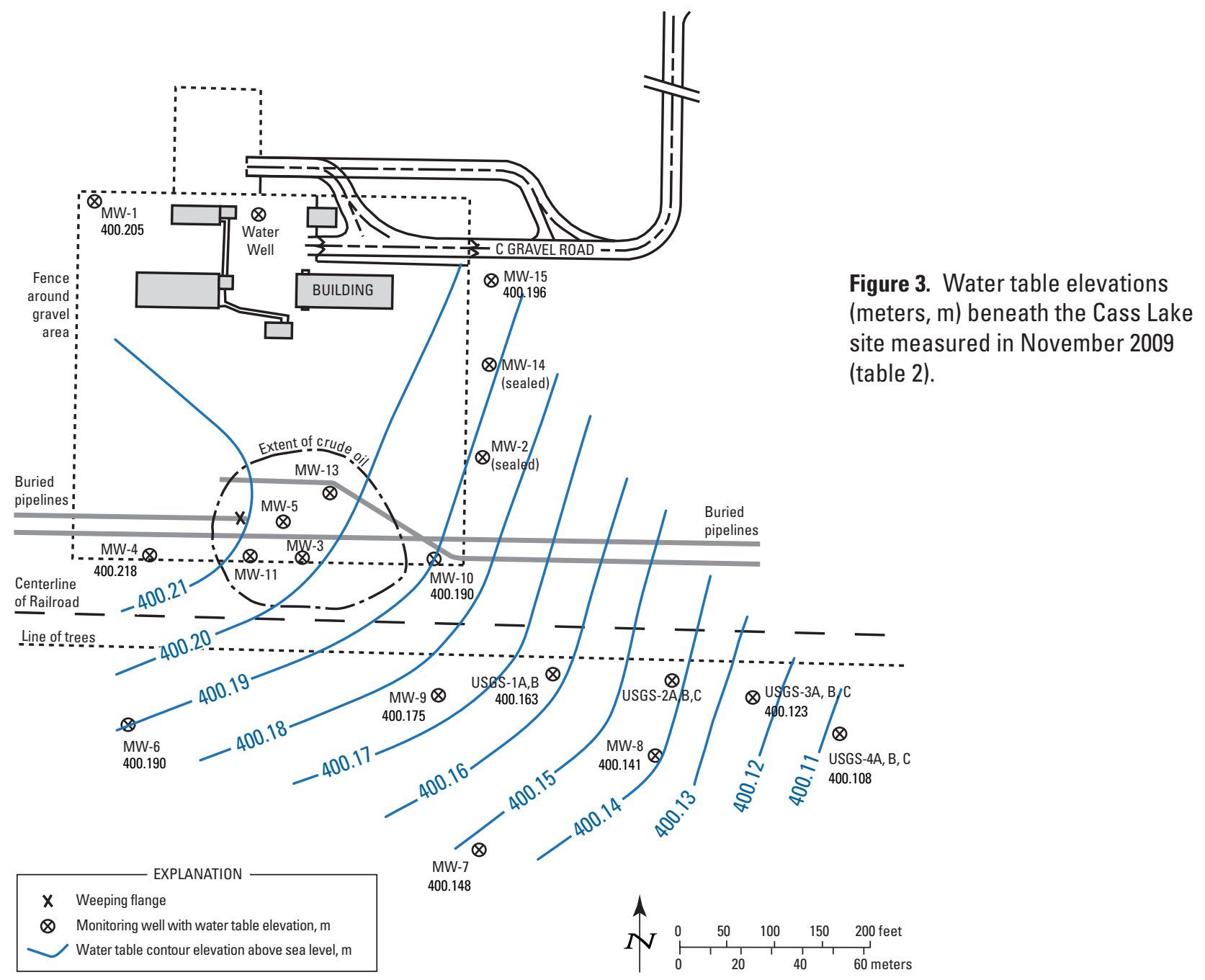


0.03 to 0.01 percent, and a hydraulic conductivity of $6 \mathrm{~m} / \mathrm{d}$ (Natural Resources Engineering Company, 2004; see also section on Site History). While the velocity estimate from this study is higher than the previous estimate for the Cass Lake site, it is similar to the estimated mean value for the Bemidji research site (22 m/yr) (Essaid and others, 2003).

\section{Distribution of Petroleum Hydrocarbons}

\section{Separate Phase Oil}

The weight percent oil, determined in triplicate for each core sample, is shown in table 5. The lowest average percent of oil in the sediments was in the C0811 (108 to $111 \mathrm{~cm}$ ) sample with an average of 0.1 percent oil. The highest oil percent is found in C0811 (70 to $82 \mathrm{~cm}$ ) with an average of 2.65 percent oil. Similar values were obtained from the two Bemidji samples (table 5).
Table 5. Selected results of oil analyses: $\delta^{13} \mathrm{C}$ values for oil extracted from sediments at the South Cass Lake Pumping Station and collected from the pipeline, weight percent of oil extracted from sediment samples, and $n$-heptadecane/pristane $\left(n-C_{17} / \mathrm{Pr}\right)$ ratio for each of the four sediment samples and the two oil samples.

\begin{tabular}{lccl}
\hline \multicolumn{1}{c}{ Sample } & $\begin{array}{c}\delta^{\mathbf{1 3}} \mathbf{C} \text {, per } \\
\text { mil }\end{array}$ & $\begin{array}{c}\text { Percent } \\
\text { oil }\end{array}$ & $n-\mathbf{C}_{\mathbf{1 7}} / \mathbf{P r}$ \\
\hline Bemidji B0801/22-36 cm & & 1.6 & 0.66 \\
Bemidji B0802/10-13 cm & & 2.6 & 0.79 \\
Cass Lake C0811/70-82 cm & -29.45 & 2.7 & 0.04 \\
Cass Lake C0811/108-111 cm & -29.24 & 0.1 & 0.04 \\
Cass Lake pipeline & -30.13 & & 2.15 \\
Cass Lake MW-3 bailed & & & 0.05 \\
\hline
\end{tabular}

${ }^{1}$ Core/Distance from top of core (centimeter, $\mathrm{cm}$, intervals). See table 3 for depth to top of cores

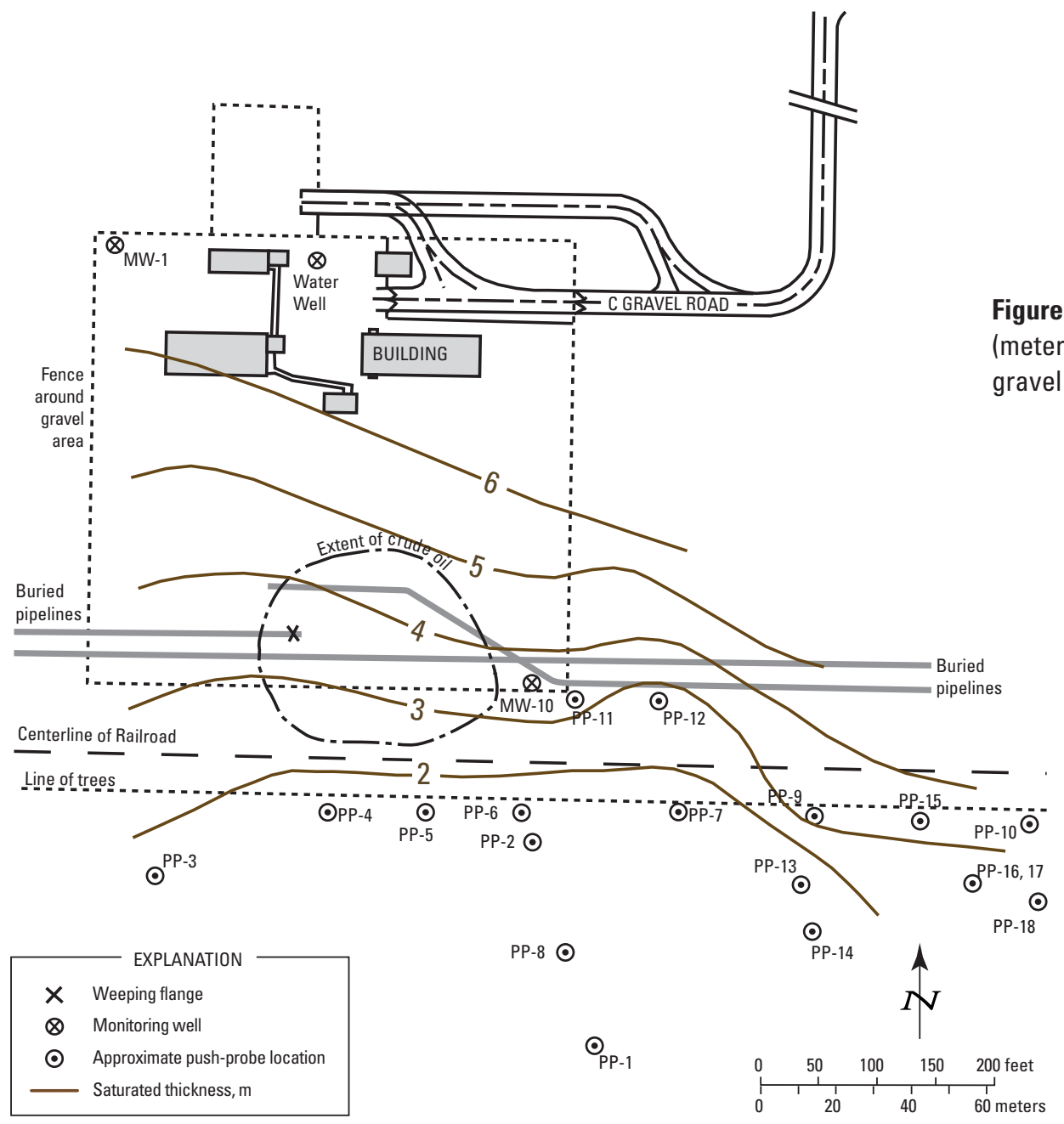




\section{Nonvolatile Hydrocarbons}

Table 5 also lists the $n$-heptadecane/pristane $\left(n-\mathrm{C}_{17} / \mathrm{Pr}\right)$ ratios and the $\delta^{13} \mathrm{C}$ values, which are indicators of biodegradation. The $n-\mathrm{C}_{17} / \mathrm{Pr}$ ratio decreases as degradation progresses because $n-\mathrm{C}_{17}$ degrades while Pr remains unchanged (Peters and others, 2005). Very low values for this ratio were obtained for all of the Cass Lake oil-body samples, indicating that the $n$-alkane fraction is highly degraded. As oil biodegrades, the $\delta^{13} \mathrm{C}$ value increases (Clark and Fritz, 1997). The change in the $\delta^{13} \mathrm{C}$ values from -30.13 per mil for the pipeline oil to -29.24 per mil in the oil body is consistent with biodegradation.

Figure $6 A$ shows the $n$-alkanes in the range of $n-C_{11}$ to $n-\mathrm{C}_{31}$ for all the sediment and oil samples (pipeline and MW-3). In order to assess the degree of degradation, the $n$-alkanes were normalized to $\mathrm{C}_{30}$ hopane, a conservative (relatively nondegradable) component of this oil. The highest values for the $n$-alkanes are from the crude oil taken directly from the pipeline. The normalized concentrations exhibit peak values in the $n-\mathrm{C}_{13}$ to $n-\mathrm{C}_{17}$ range, decreasing linearly in the range of $n-\mathrm{C}_{19}$ to $n-\mathrm{C}_{31}$. The most highly degraded oils are

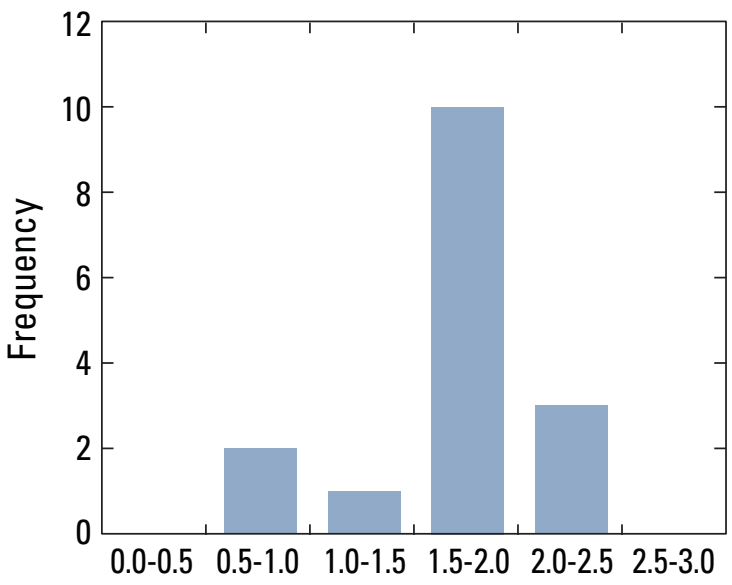

Log hydraulic conductivity range, $\mathrm{m} / \mathrm{d}$

Figure 5. Frequency distribution of log hydraulic conductivity in meters per day $(\mathrm{m} / \mathrm{d})$ determined from grain size analyses of 16 samples collected at the Cass Lake site.
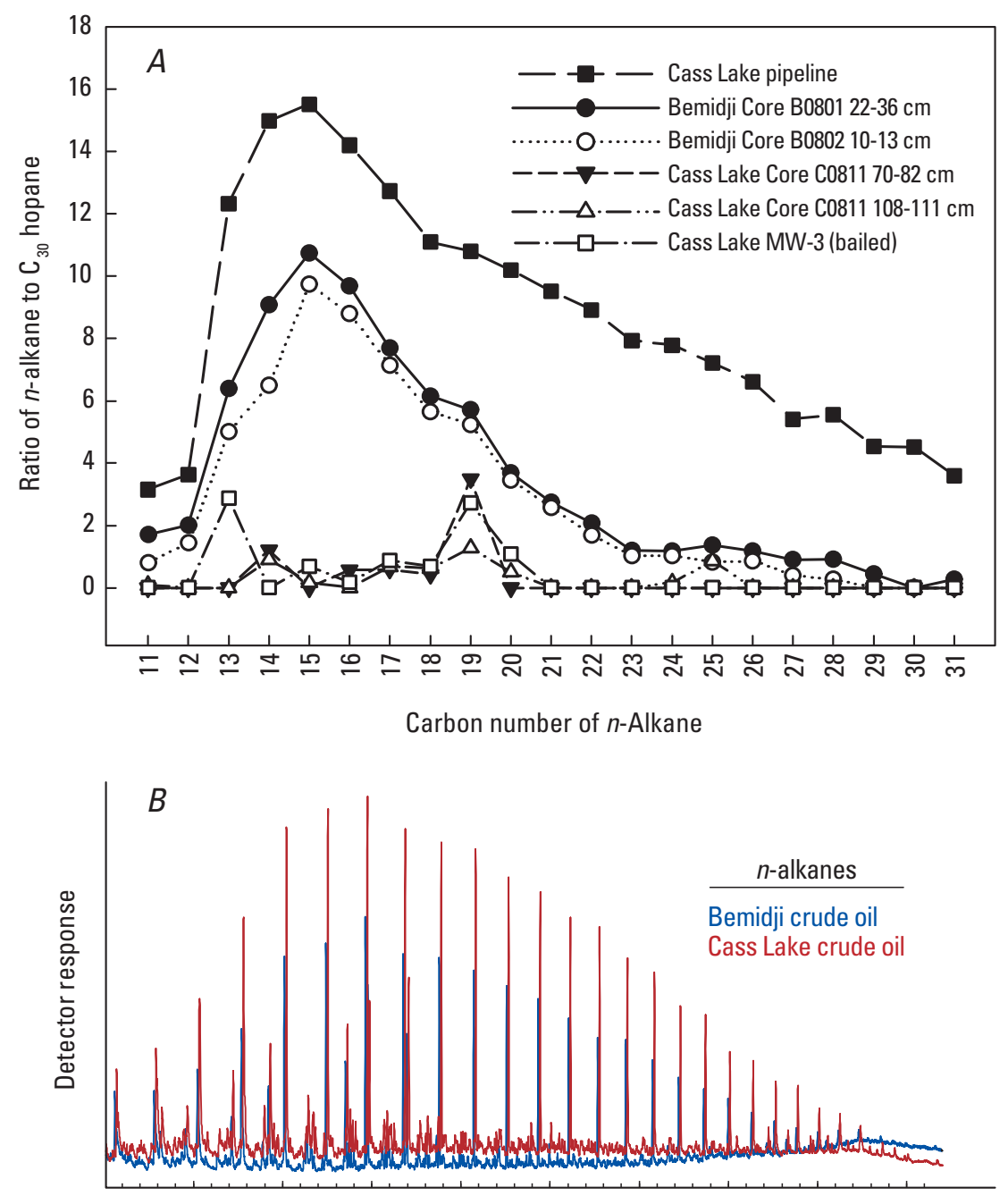

Figure 6. Comparison of $n$-alkanes in oil and sediment samples from the Cass Lake and Bemidji sites as determined by gas chromatograph/mass spectrometry. $A$, Ratio of $n$-alkanes to $C_{30}$ hopane in oil samples from Cass Lake and in Cass Lake and Bemidji sediment cores. Distances from top of core in legend are in centimeters $(\mathrm{cm}) . B$, Comparison of $n$-alkane distributions in Bemidji pipeline oil from 1984 and Cass Lake pipeline oil from 2008 showing the similarity of the two samples. The difference in peak heights is caused by instrument differences between 2002 and 2008. Elution time of $n$-alkanes increases with number of carbons. 
from the Cass Lake sediment samples C0811 (70 to $82 \mathrm{~cm}$ ) and C0811 (108 to $111 \mathrm{~cm})$ and the sample from MW-3. The concentrations for all $n$-alkanes and the geochemical ratios $\left(n-\mathrm{C}_{17} / \mathrm{Pr}\right.$ ) for samples C0811 (70 to $82 \mathrm{~cm}$ ) and C0811 (108 to $111 \mathrm{~cm}$ ) were similar to the oil sample bailed from MW-3 (table 5). The similarity of floating oil from one location and oil extracted from sediments in another location suggests the degradation state is uniform over a sizeable area of the oil body. All of the Cass Lake samples are highly degraded compared to the two Bemidji samples (fig. 6A, table 5).

To determine if the Cass Lake oil came from the same original source as the Bemidji oil, the Cass Lake pipeline sample was compared to Bemidji source oil collected from the pipeline in 1984 and analyzed in 2002 (Hostettler and others, 2004). The analysis was based on 19 ratios developed for comparing oil sources (Hostettler and others, 2004; Peters and others, 2008) that were computed from the data for each oil sample. The results showed that all ratios were within 20 percent and 13 ratios were within 10 percent of each other. The three highest differences in ratios were attributed to instrument differences between when the Bemidji samples were analyzed in 2002 and when the Cass Lake samples were analyzed in 2008 . Figure $6 B$ shows that the $n$-alkane fractions in the two oils are identical. The difference in peak heights is caused by instrument differences between 2002 and 2008. The conclusion is that the two oils are from the same source.

\section{Volatile Hydrocarbons}

The composition of volatile hydrocarbons in crude oil from well MW-3 was compared to that in the pipeline oil and oil-contaminated sediment. The concentrations of compounds analyzed are in table 6 and figure 7. Two samples were analyzed from MW-3, and the average of the two results is reported. The concentrations of hydrocarbons are reported in milligram per gram ( $\mathrm{mg} / \mathrm{g}$ ) oil for the oils and in $\mathrm{mg} / \mathrm{g}$ dryweight sediment for the sediment.

Assuming the oil at MW-3 and in sediment at C0811-91 had the same composition initially as the pipeline oil, comparisons can be made on changes in composition over time. Evidence that the pipeline oil might not have varied significantly over time was obtained from comparison of the VHC from the Bemidji pipeline oil (sample obtained in 1984) to the Cass

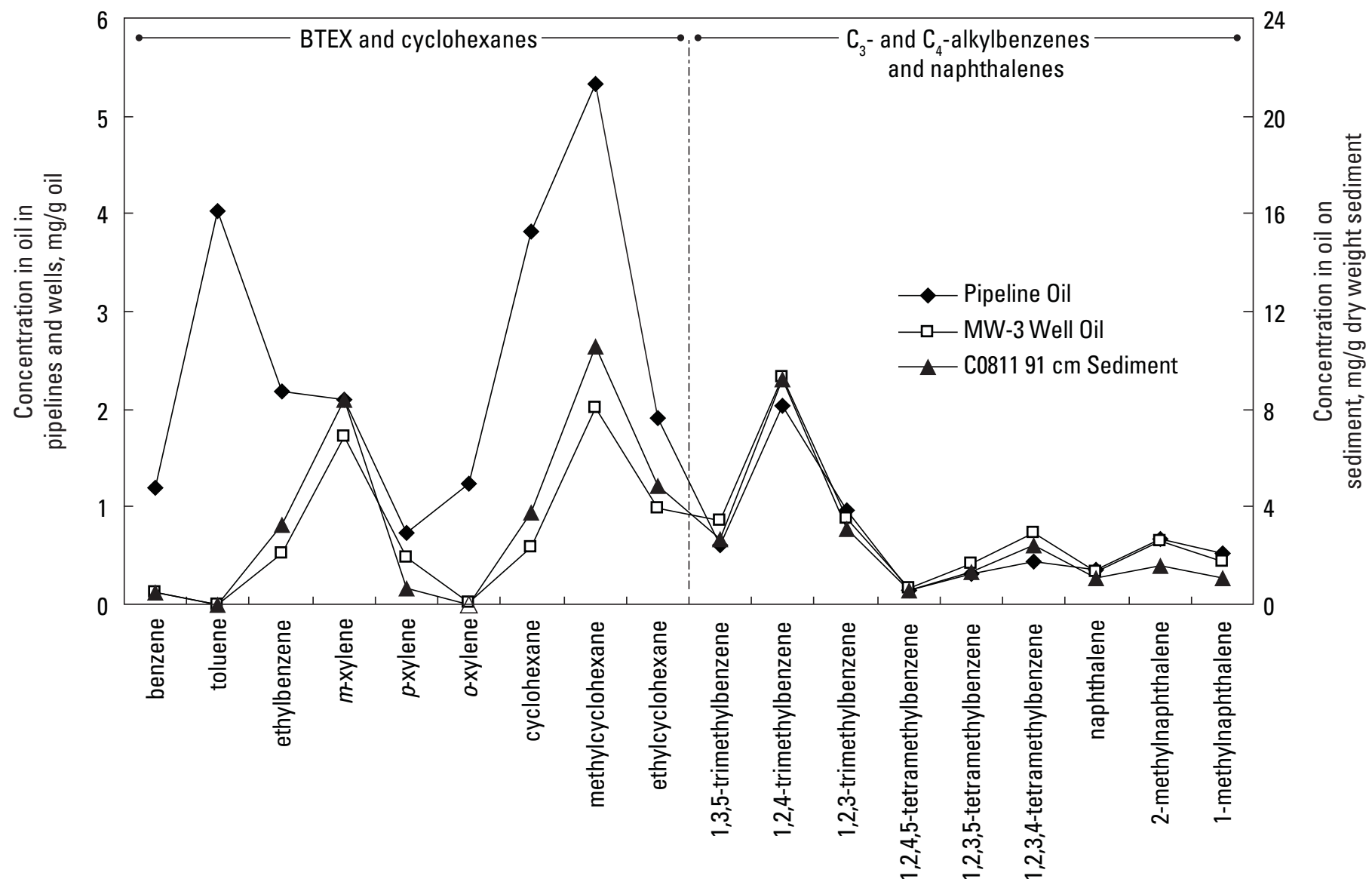

Figure 7. Comparison of concentrations of benzene, toluene, ethylbenzene, and xylenes (BTEX); cycloalkanes; methylbenzenes; and methylnaphthalenes (milligrams per gram, $\mathrm{mg} / \mathrm{g}$ ) in Cass Lake spilled oil, Cass Lake pipeline oil, and oil extracted from sediment. Distance from top of core C0811 is 91 centimeters $(\mathrm{cm})$. 
Lake pipeline oil (sample obtained in 2008), which indicated that the compositions of the oils are very similar. Some caution should be applied because there are no data indicating that the composition of the leaking oil was constant over time.

The VHC in the well oil and oil-contaminated sediment, compared to the VHC in pipeline oil, fall into three groups based on structure and degradation from biological and physical processes. In the first group, BTEX and the cyclohexanes are attenuated within the oil body (fig. 7). The most abundant compound in this group is methylcyclohexane, and about 60 percent of it is depleted in the MW-3 well oil compared to the pipeline oil. About 90 percent of the benzene is depleted in the well oil. Some components are below detection limit, such as toluene and $o$-xylene, whereas others, such as $m$ - and $p$-xylenes, were relatively unchanged. In the second group, the $\mathrm{C}_{3}$ - and $\mathrm{C}_{4}$-alkylbenzenes, naphthalene, and the methylnaphthalenes show similar patterns between the pipeline, well oil, and sediment. There is little or no loss of these compounds in the well oil compared to the pipeline oil, and some of the trimethylbenzenes and tetramethylbenzenes are higher in concentration in the well oil compared to the pipeline oil. The sediment sample has a similar distribution of VHC as in the well oil. In the third group, the normal hydrocarbons in the $\mathrm{C}_{6}$ to $\mathrm{C}_{12}$ range are present in the pipeline oil and not detected in the well oil or in the sediment sample (table 6).

The loss of BTEX in the well oil and oil-contaminated sediment compared to the pipeline oil is likely due primarily

Table 6. Results of analyses of oil collected from a South Cass Lake Pumping Station pipeline (2008), bailed from MW-3 (2007), and extracted from C0811-91 centimeters (cm) (2008).

[ND, not detected. Results in milligrams per gram $(\mathrm{mg} / \mathrm{g})]$

\begin{tabular}{|c|c|c|c|}
\hline Hydrocarbons identified & $\begin{array}{l}\text { Pipeline oil, } \\
\text { mg/g oil }\end{array}$ & $\begin{array}{c}\text { Well MW-3 oil, mg/g } \\
\text { oil }^{1}\end{array}$ & $\begin{array}{c}\text { C0811-91 cm, mg/g } \\
\text { dry weight sediment }\end{array}$ \\
\hline benzene & 1.186 & 0.132 & 0.494 \\
\hline toluene & 4.025 & ND & ND \\
\hline ethylbenzene & 2.182 & 0.514 & 3.312 \\
\hline$o$-xylene & 1.231 & 0.022 & ND \\
\hline$m$-xylene & 2.089 & 1.711 & 8.411 \\
\hline$p$-xylene & 0.737 & 0.486 & 0.702 \\
\hline cyclohexane $^{2}$ & 3.808 & 0.584 & 3.783 \\
\hline methylcyclohexane ${ }^{2}$ & 5.326 & 2.010 & 10.543 \\
\hline ethylcyclohexane ${ }^{2}$ & 1.905 & 0.980 & 4.888 \\
\hline 1,3,5-trimethylbenzene & 0.602 & 0.853 & 2.727 \\
\hline 1,2,4-trimethylbenzene & 2.037 & 2.319 & 9.238 \\
\hline 1,2,3-trimethylbenzene & 0.970 & 0.871 & 3.105 \\
\hline 1,2,3,4-tetramethylbenzene ${ }^{2}$ & 0.439 & 0.742 & 2.455 \\
\hline 1,2,3,5-tetramethylbenzene ${ }^{2}$ & 0.305 & 0.417 & 1.345 \\
\hline $1,2,4,5$-tetramethylbenzene ${ }^{2}$ & 0.138 & 0.175 & 0.567 \\
\hline naphthalene & 0.360 & 0.342 & 1.106 \\
\hline 1-methylnaphthalene ${ }^{2}$ & 0.522 & 0.446 & 1.088 \\
\hline 2-methylnaphthalene ${ }^{2}$ & 0.674 & 0.650 & 1.635 \\
\hline hexane & 10.400 & ND & ND \\
\hline heptane & 15.391 & ND & ND \\
\hline octane & 6.952 & ND & ND \\
\hline nonane & 7.951 & ND & ND \\
\hline decane & 7.873 & ND & ND \\
\hline undecane & 7.687 & ND & ND \\
\hline dodecane & 6.037 & ND & ND \\
\hline
\end{tabular}


to biodegradation. The observed pattern of greatest to least amount of loss is toluene $=o$-xylene $>$ benzene $>$ ethylbenzene $>p$ - and $m$-xylene. The well oil and oil-contaminated sediment are in anoxic environments, and their similar loss patterns suggest that the same processes are occurring in this part of the aquifer. Although the two samples were collected in a contaminated part of the aquifer, the oil is floating on the groundwater surface at MW-3 at an elevation of approximately $400.04 \mathrm{~m}$, whereas the oily sediment sample was collected about $17 \mathrm{~m}$ to the north at an elevation of $399.90 \mathrm{~m}$.

The observed pattern of loss is similar to the loss of BTEX in groundwater at the Bemidji site (Eganhouse and others, 1996). The complete loss of $o$-xylene and not the $m$ - and $p$-xylenes is an indication of the importance of microbial degradation, because these compounds have similar physicochemical properties. The biodegradation of BTEX under anaerobic conditions is well documented in the literature (Alvarez and Vogel, 1991). The considerable depletion of cyclohexane, methylcyclohexane, and ethylcyclohexane in the Cass Lake well oil relative to the pipeline oil (fig. 7) is somewhat surprising, because these compounds are relatively insoluble in water and more difficult to biodegrade under anoxic conditions than BTEX and normal hydrocarbons (Perry, 1984).

The $\mathrm{C}_{3}$ - and $\mathrm{C}_{4}$-alkylbenzenes, naphthalene, and the dimethylnaphthalenes are only slightly soluble in water and are known to degrade under some conditions. Although some trimethyl- and tetramethylbenzenes have been shown to degrade under anoxic conditions in groundwater (Cozzarelli and others, 1990), it is possible that the oil body is too toxic for their biodegradation. Likewise, naphthalene and the methylnaphthalenes are more likely to be degraded under oxic conditions (Mihelcic and Luthy, 1988) but were shown to degrade under anaerobic conditions by sulfate-reducers (Meckenstock and others, 2000). In this environment these compounds are stable compared to BTEX, cyclohexanes, and normal hydrocarbons. The finding that several alkylated benzenes were in higher concentrations in the well oil compared to the pipeline oil suggests that they are resistant to degradation and becoming enriched as other compounds are being attenuated.

The normal hydrocarbons in the $\mathrm{C}_{6}$ to $\mathrm{C}_{12}$ range appear to be labile under the conditions at the site. This is consistent with a study at the Bemijdi site (Bekins and others, 2005a). Although normal hydrocarbons are not detected in the Cass Lake well oil or in the oil-contaminated sediment, alkylated hydrocarbons are still abundant, but they were not analyzed quantitatively in this study. Alkylated or branched-chained hydrocarbons are known to be more difficult to degrade than normal alkanes (Solano-Serena and others, 1999).

Although most of the VHC in the Cass Lake oil body are attenuated over time in a pattern that is consistent with that observed at the Bemidji site (Eganhouse and others, 1993; and M.J. Baedecker, USGS, unpublished data, 2009), some differences are notable. For example, normal hydrocarbons from $\mathrm{C}_{6}$ to $\mathrm{C}_{12}$ are absent in the Cass Lake well oil and in the sediment sample. In contrast, at the Bemidji site normal hydrocarbons from $\mathrm{C}_{6}$ to $\mathrm{C}_{11}$ were found in all the oil samples analyzed.
Also, at the Bemidji site the concentrations of the cyclohexanes identified in the well oils and pipeline oil were similar, whereas in the Cass Lake well oil and sediment sample these compounds were depleted compared to the pipeline oil. These results indicate that the Cass Lake oils floating on the groundwater and in the sediment are more degraded than are the oils at the Bemidji site.

\section{Groundwater Plume}

Figures 8 and 9 show plan-view and cross-section plots, respectively, of benzene concentrations measured in the pushprobe surveys conducted in September 2007 and May 2008. These data provide the most complete three-dimensional picture of the plume, with 68 different sample locations. In figure $8 A$ the contours are based on the highest benzene concentration measured at any depth. Concentrations used for the contours are written next to the sample location. The data show that the leading edge of the $10-\mu \mathrm{g} / \mathrm{L}$ benzene plume lies in the wooded area south of the railroad tracks, about 150 m east of well MW-10. The dissolved plume of BTEX extends eastsoutheast from MW-10. This direction of transport represents an eastward deviation from the generally southeast direction of regional groundwater flow. The thinning of the sand and gravel aquifer to the south of the site (fig. 4) appears to cause the eastward diversion of the groundwater flow (fig. 3) and plume.

Figure $9 A$ shows a cross section of the benzene concentrations along the centerline of the plume marked in figure $8 B$. The contamination occurs mainly in the sand-and-gravel layer overlying the till. The benzene plume spans the vertical interval from the water table to the base of the sand-and-gravel aquifer. There is some indication that the plume splits vertically at PP-9, located $30 \mathrm{~m}$ downgradient from PP-7, where a low permeability layer impeded sample collection in the center of the aquifer.

The well nests USGS-1, USGS-2, USGS-3, and USGS-4 (fig. 2) were installed to monitor temporal changes along the axis of the plume. In some cases their locations were several meters south of the closest push-probe site in order to provide access for the drill rig through the cleared area in the woods. Figure $9 B$ is a comparison between the push-probe data and the USGS wells, showing that benzene concentrations at the USGS-1 and USGS-2 well nests are considerably lower than at PP-7 and PP-9, respectively.

Several lines of evidence indicate that these differences are not caused by sampling methodology or differences in the analytical methods but are due to the location of the plume. For example, in May 2007, a sample was collected from MW-10 and analyzed in the field, resulting in a value of 2,751 $\mu \mathrm{g} / \mathrm{L}$. Then in June 2008 another sample was collected and analyzed at the NWQL, resulting in a value of $3,146 \mu \mathrm{g} / \mathrm{L}$. These results are in the same order of magnitude and are within the yearly variation expected within the plume, thus indicating that the sampling and analytical methods gave comparable results during May 2007 and June 2008.

Results from the analyses for redox constituents (table 7) indicate that well nests USGS-1 and USGS-2 are located on 

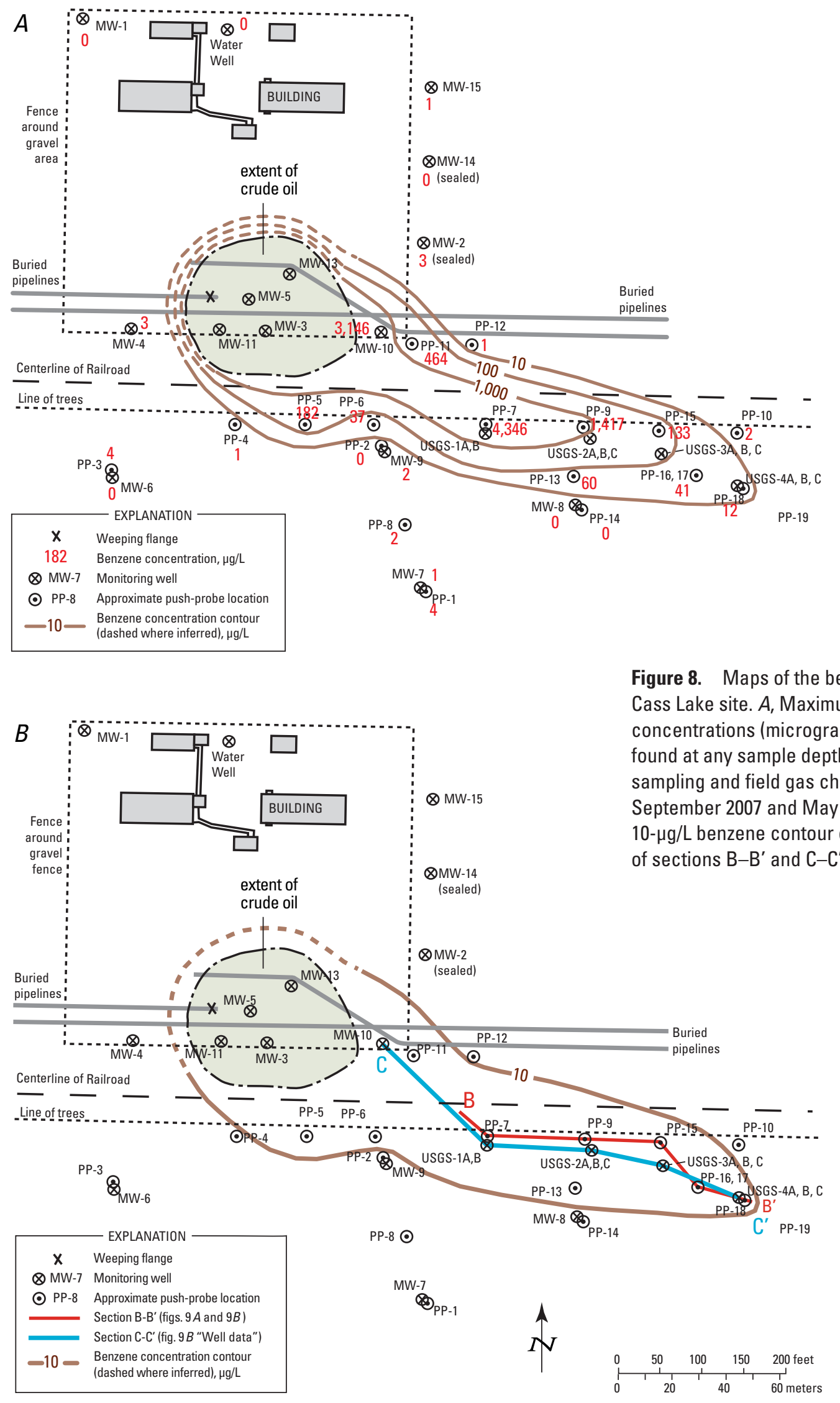
Table 7. Values of selected parameters in water from the background well (MW-1) and selected contaminated wells at the Cass Lake site.

[Spec. cond., specific conductivity in microsiemens $(\mu \mathrm{S})$; concentrations in milligrams per liter $(\mathrm{mg} / \mathrm{L})$ and micrograms per liter $(\mu \mathrm{g} / \mathrm{L})$; TDOC, total dissolved organic carbon; na, data not available.]

\begin{tabular}{|c|c|c|c|c|c|c|c|c|c|c|c|c|c|}
\hline Parameter & $\begin{array}{c}\text { MW- } \\
1\end{array}$ & $\begin{array}{c}\text { MW- } \\
10\end{array}$ & $\begin{array}{l}\text { USGS- } \\
1 A\end{array}$ & $\begin{array}{c}\text { USGS- } \\
\text { 1B }\end{array}$ & $\begin{array}{c}\text { USGS- } \\
\text { 2A }\end{array}$ & $\begin{array}{c}\text { USGS- } \\
\text { 2B }\end{array}$ & USGS-2C & $\begin{array}{l}\text { USGS- } \\
\text { 3A }\end{array}$ & $\begin{array}{l}\text { USGS- } \\
\text { 3B }\end{array}$ & $\begin{array}{l}\text { USGS- } \\
\text { 3C }\end{array}$ & $\begin{array}{c}\text { USGS- } \\
4 A\end{array}$ & $\begin{array}{c}\text { USGS- } \\
\text { 4B }\end{array}$ & $\begin{array}{l}\text { USGS- } \\
\text { 4C }\end{array}$ \\
\hline pH & 7.33 & 6.57 & 7.13 & 7.07 & 6.91 & 6.99 & 7.07 & 7.12 & 7.30 & 7.04 & 7.10 & 7.07 & 6.94 \\
\hline Spec. cond. $(\mu S)$ & 433 & 1,012 & 526 & 560 & 610 & 617 & 677 & 634 & 693 & 749 & 658 & 691 & 771 \\
\hline Alkalinity (mg/L) & 232.5 & 675.1 & 366.8 & 378.0 & 372.8 & 395.8 & 470.8 & 470.2 & 488.1 & 561.3 & 453.4 & 505.6 & 521.9 \\
\hline TDOC (mg/L) & 1.31 & 20.97 & 0.77 & 0.64 & 1.72 & 2.58 & 4.26 & 4.96 & 8.68 & 3.47 & 3.36 & 5.52 & 1.30 \\
\hline Benzene $(\mu \mathrm{g} / \mathrm{L})$ & na & 3,146 & 0.27 & 0.50 & 1.31 & 2.07 & 2.12 & 39.52 & 143.10 & 2.94 & $<0.50$ & 0.59 & $<0.50$ \\
\hline $\mathrm{O}_{2}(\mathrm{mg} / \mathrm{L})$ & 9.57 & 0.00 & 0.01 & 0.00 & 0.00 & 0.00 & 0.00 & 0.30 & 0.00 & 0.00 & $<0.01$ & 0.01 & 0.01 \\
\hline $\mathrm{NO}_{3}^{-}(\mathrm{mg} / \mathrm{L})$ & 0.45 & 1.20 & $<0.52$ & $<0.55$ & $<0.59$ & $<0.58$ & $<0.51$ & $<0.62$ & $<0.66$ & 1.12 & $<0.58$ & $<0.56$ & 15.73 \\
\hline $\mathrm{Fe}^{2+}(\mathrm{mg} / \mathrm{L})$ & na & 25.60 & 1.80 & 7.10 & 19.67 & 16.46 & 15.31 & 8.10 & 17.76 & 1.24 & 1.56 & 1.59 & 1.21 \\
\hline $\mathrm{Mn}^{2+}(\mathrm{mg} / \mathrm{L})$ & na & 0.58 & 2.50 & 2.09 & 1.46 & 1.02 & 1.02 & 1.96 & 1.23 & 1.43 & 1.60 & 2.48 & 0.18 \\
\hline $\mathrm{NH}_{4}^{+}(\mathrm{mg} / \mathrm{L})$ & 0.23 & 8.99 & 0.26 & 1.10 & 3.83 & 6.12 & 3.41 & 2.10 & na & 0.75 & 0.26 & 0.75 & 0.19 \\
\hline $\mathrm{SO}_{4}^{2-}(\mathrm{mg} / \mathrm{L})$ & 1.30 & 0.82 & 4.95 & 5.40 & 5.14 & 3.78 & 2.00 & 0.95 & 0.95 & 5.42 & 2.30 & 0.98 & 8.29 \\
\hline $\mathrm{CH}_{4}(\mathrm{mg} / \mathrm{L})$ & 0.04 & 19.26 & 0.45 & 0.69 & 0.55 & 0.55 & 0.61 & 2.73 & 3.12 & 0.07 & 0.08 & 0.15 & 0.01 \\
\hline
\end{tabular}




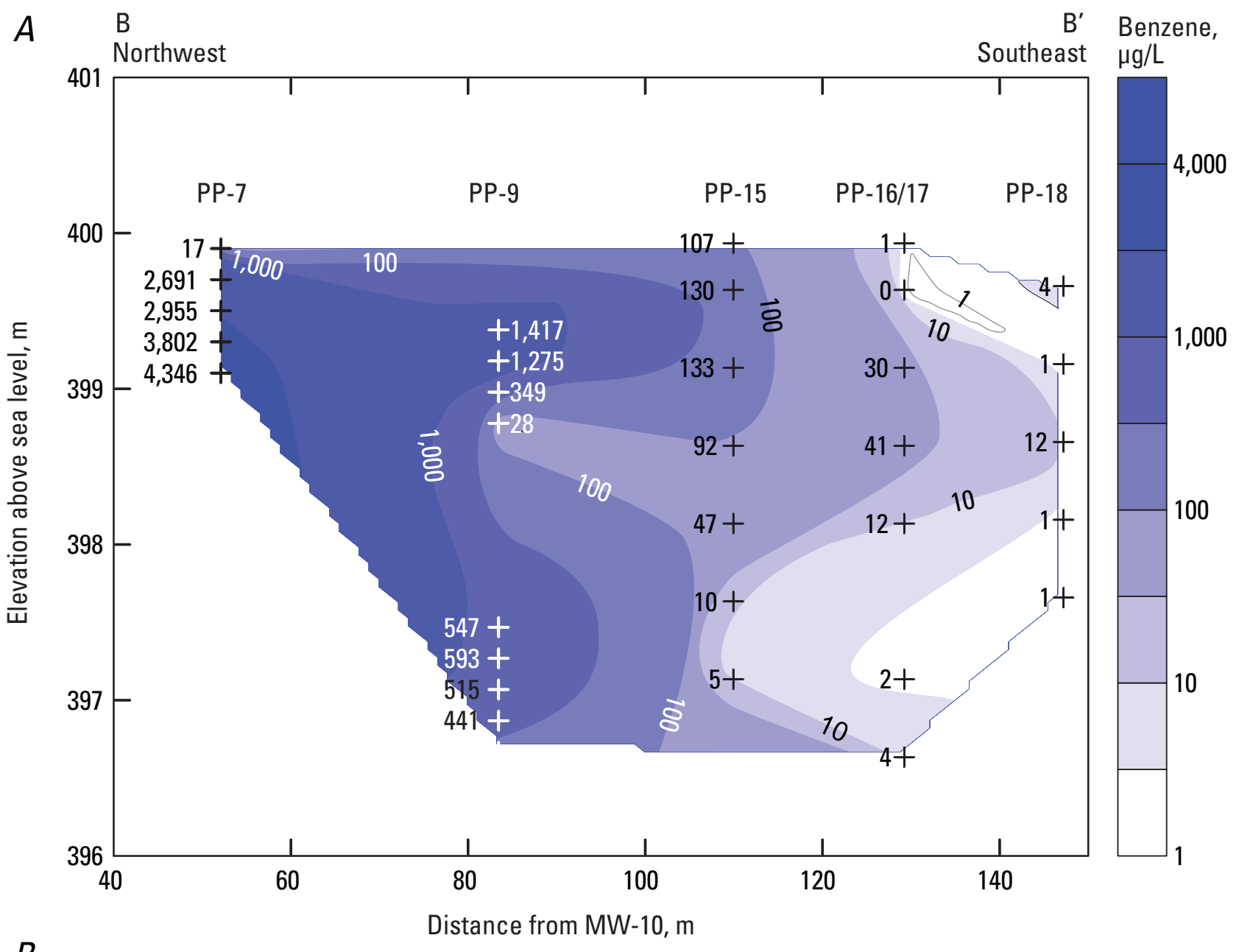

B

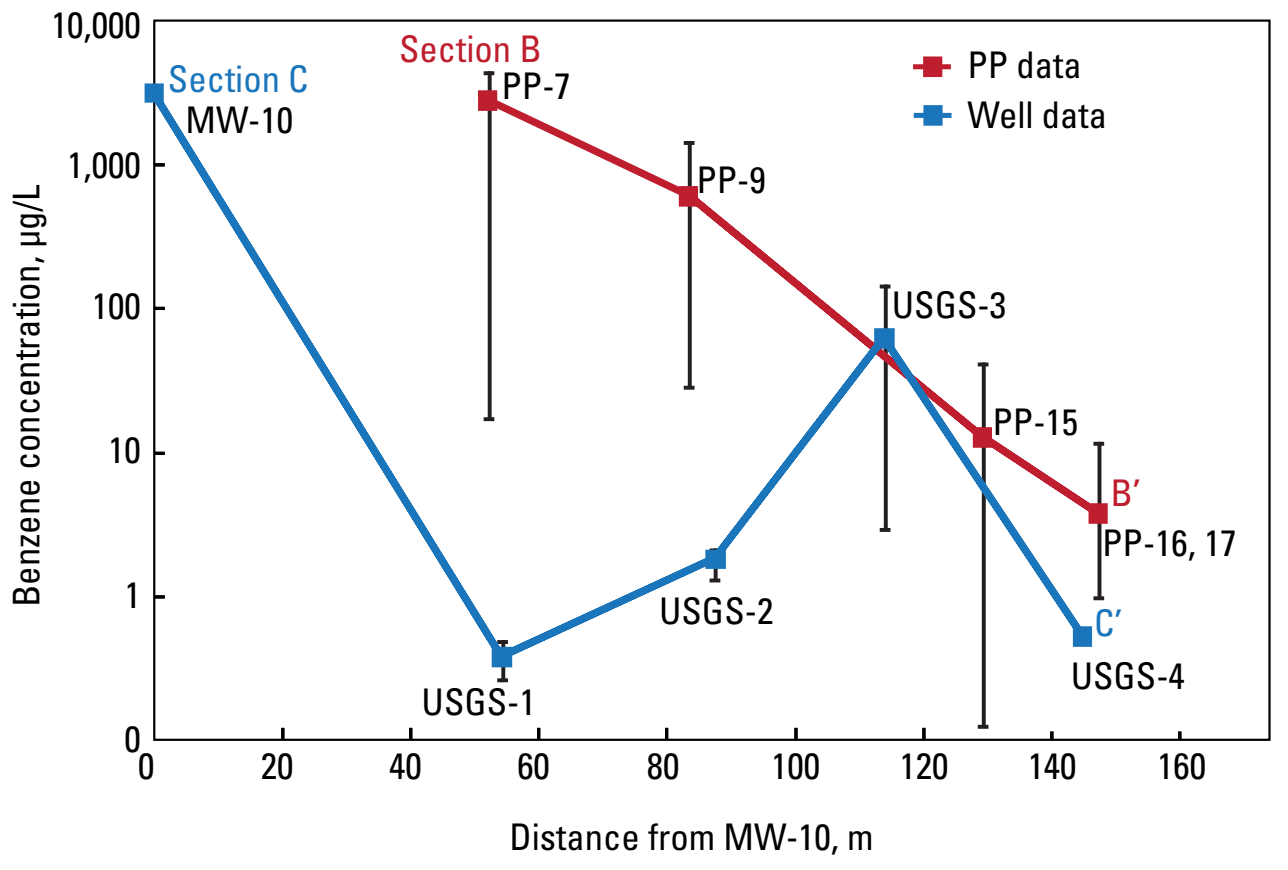

Figure 9. Benzene concentrations (micrograms per liter, $\mu \mathrm{g} / \mathrm{L}$ ) in the Cass Lake plume. Elevations and distances are in meters (m). $A$, Benzene concentrations along a cross section through the plume based on push-probe sampling and field gas chromatograph analyses, September 2007 and May 2008 (section line shown in figure $8 B$, section $\left.\mathrm{B}-\mathrm{B}^{\prime}\right)$. $B$, Comparison between benzene concentrations measured in the push-probe profiles and in the USGS wells. Error bars are maximum and minimum values measured in each vertical profile (section line shown in figure $8 B$, section $C-C^{\prime}$ ). 
the lateral edge of the plume. In particular, dissolved methane concentrations are lower and sulfate concentrations higher than at USGS-3, indicating less reduced conditions typical of the periphery of the plume. Since the USGS-1 nest is located only about $5 \mathrm{~m}$ from PP-7, these results show that the areal extent of the plume is quite limited along the southern edge, probably a result of the shallow depth of the glacial till. In summary, the combined dataset from all of the groundwater sampling indicates that the Cass Lake plume is narrow ( 40 to $60 \mathrm{~m}$ in the middle) compared to the Bemidji plume (60 to $80 \mathrm{~m}$ ).

Benzene concentrations from PP-15 through PP-18 are comparable to values from well nests USGS-3 and USGS-4, indicating that these wells lie in or near the center of the mapped plume. Benzene concentrations in the USGS-4 nest were all below $5 \mu \mathrm{g} / \mathrm{L}$; thus this well is suitably located as a monitoring well for detecting future plume expansion.

\section{Differences Between Datasets}

The three-dimensional picture of the plume in figures 8 and 9 shows some differences with other data from the Cass Lake site. Typically, the highest concentrations in petroleum plumes become deeper with distance from the source as clean recharge water enters the aquifer above the plume (National Research Council, 2000). This increasing depth with distance is apparent in the benzene data cross section in figure $9 \mathrm{~A}$. Previous groundwater data from the Cass Lake site are based on samples collected near the water table from either the MW wells or temporary Geoprobe boreholes.

To understand the three-dimensional nature of the Cass Lake plume, direct comparison of data collected from nearby locations is instructive. Boreholes PP-7 and GP-16 are separated by about $10 \mathrm{~m}$ (fig. 2). At PP-7, the concentration of benzene detected in 2007 at the deepest level was $4,346 \mu \mathrm{g} / \mathrm{L}$ (fig. 9A). In contrast, the benzene concentration at GP-16 was only $19 \mu \mathrm{g} / \mathrm{L}$ in 2003 (Natural Resources Engineering Company, 2003). Although the samples were collected in different years, using different equipment, and analyzed with different instruments, the primary source of this difference may be the depth from which the samples were collected. The borehole $\log$ for GP-16 indicates that the water sample was collected at a depth of about $0.3 \mathrm{~m}$ below the water table (Natural Resources Engineering Company, 2003). For PP-7, samples were collected at $0.2-\mathrm{m}$ intervals from $0.2 \mathrm{~m}$ to $1.0 \mathrm{~m}$ below the water table. In the $0.2-\mathrm{m}$ sample benzene was $17 \mu \mathrm{g} / \mathrm{L}$ (fig. $6 A$ ), which is comparable to the GP-16 value of $19 \mu \mathrm{g} / \mathrm{L}$ at $0.3 \mathrm{~m}$ below the water table. Concentrations in PP-7 increased with depth, reaching the maximum value of $4,346 \mu \mathrm{g} / \mathrm{L}$ in the deepest sample collected at $1.0 \mathrm{~m}$ below the water table. No deeper samples were collected at PP-7 because the base of the sand-and-gravel aquifer was encountered just below this depth.

Longer well screens may also lead to lower concentrations than observed in USGS wells and push-probes, if water from near the edge of the Cass Lake plume mixes with water from the center. This effect is apparent when the push-probe data are compared to well data. The push-probe screen con- sisted of ten 1.0-cm-diameter ports distributed over a $10-\mathrm{cm}$ vertical interval. By comparison, the USGS well screens are slightly longer at $30 \mathrm{~cm}$, but the existing monitoring-well screens are $3.05 \mathrm{~m}$ long. In May 2007, the concentration of benzene in MW-10 was 2,751 $\mu \mathrm{g} / \mathrm{L}$, whereas a peak value of $4,346 \mu \mathrm{g} / \mathrm{L}$ was found at PP-7 using the smaller push-probe screen. If all samples from $0.20 \mathrm{~m}$ to $1.0 \mathrm{~m}$ at PP-7 are averaged, the resulting value of $2,762 \mu \mathrm{g} / \mathrm{L}$ is closely comparable to the MW-10 value.

\section{Distribution of Redox Species}

\section{Groundwater}

Analysis of the water chemistry in wells located upgradient and downgradient from the oil body indicates that biodegradation at the Cass Lake site is occurring by the five primary reactions in table 1: oxygen reduction, nitrate ammonification, iron reduction, sulfate reduction, and methanogenesis. Manganese is not a major electron acceptor at the Cass Lake site and will not be discussed. Well MW-1 is representative of the background aquifer unaffected by the oil spill, and MW-10 is the most contaminated well located outside the oil (table 7).

Figure $10 \mathrm{~A}$ is a plan-view contour map of groundwater concentrations of dissolved reduced iron (Fe(II)), a product of degradation by iron reduction. The contours are based on the highest value measured at any depth during the pushprobe survey and the concentration of reduced iron in the most contaminated monitoring well outside of the oil (MW10). Reduced iron concentrations are highest near the source of the contamination at MW-10 (23.52 mg/L), decreasing to below $1 \mathrm{mg} / \mathrm{L}$ downgradient and on the sides of the plume.

Concentrations of reduced iron decrease as water containing oxygen mixes with the plume along the edges, oxidizing $\mathrm{Fe}(\mathrm{II})$ to $\mathrm{Fe}(\mathrm{III})$. The $\mathrm{Fe}(\mathrm{III})$ is insoluble and forms coatings on the sediments, resulting in the observed decrease in dissolved $\mathrm{Fe}(\mathrm{II})$. Because dissolved $\mathrm{Fe}(\mathrm{II})$ is only present where oxygen is absent, the $1-\mathrm{mg} / \mathrm{L}$ contour of dissolved Fe(II) provides an indication of the extent of the anaerobic portion of the plume (fig. 10B). Whereas the background groundwater at MW-1 is almost saturated with DO, groundwater at MW-10 and all the wells downgradient from the oil are anoxic, with DO concentrations below detection.

Figures $11 A-D$ are cross-section contour maps of redox species along the line of section D-D' shown in figure $10 B$. Ammonia, a product of nitrate ammonification, is low in the background well but increases in the plume (table 7, fig. $11 A$ ). The concentrations of reduced iron increase from the background well to well MW-10 and then decrease from the source of contamination to the downgradient wells (table 7 , fig. $11 B$ ). The concentration of sulfate, an electron acceptor, is higher at the background well than in well MW-10, indicating that sulfate is consumed by degradation coupled to sulfate 

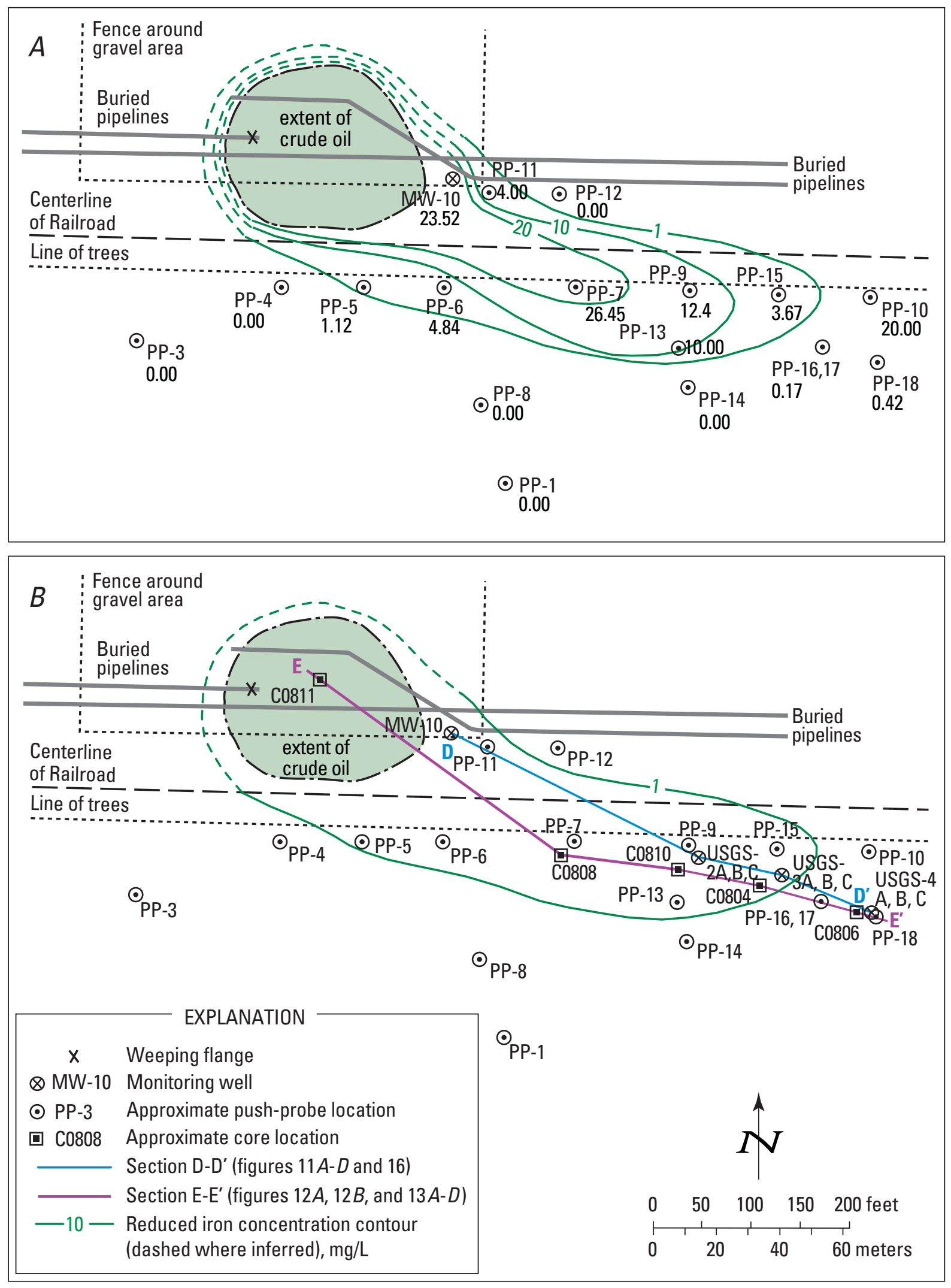

Figure 10. Maps of reduced iron (Fe(II), in milligrams per liter, $\mathrm{mg} / \mathrm{L})$ in the Cass Lake plume. $A$, Contour plot of concentrations of $\mathrm{Fe}(\mathrm{II})$ in groundwater based on maximum value measured in push-probe profiles. $B$, Anaerobic outline of the plume, which is defined by the 1-mg/L Fe(II) contour line. Also shown are lines of section for figures 11, 12, 13, and 16. 


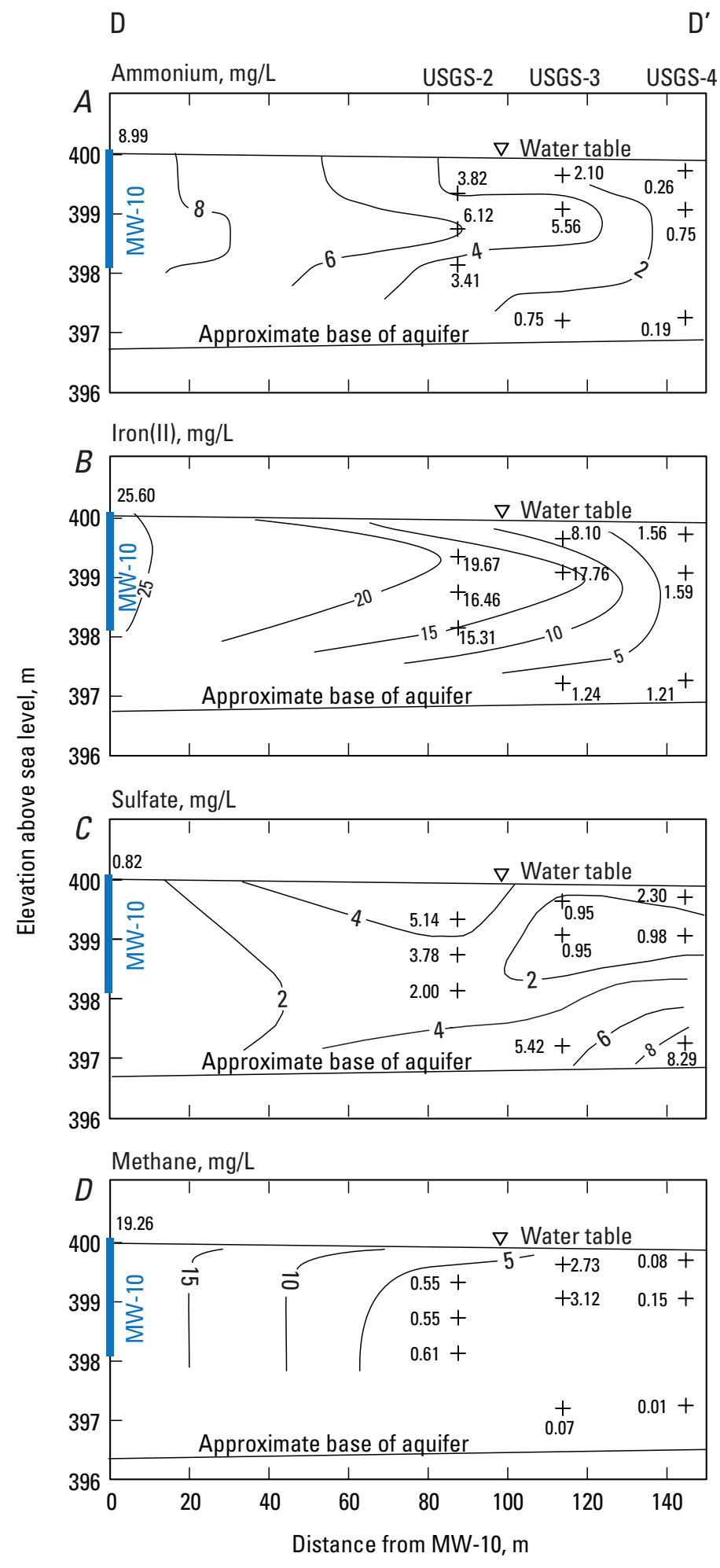

Figure 11. Concentrations of redox derivatives (milligrams per liter, $\mathrm{mg} / \mathrm{L}$ ) along line of section $\mathrm{D}-\mathrm{D}^{\prime}$ in figure $10 B$ based on data from USGS wells and MW-10 sampled in June 2008. Constant concentrations across the well screen were used for MW- 10 . Elevations and distances are in meters (m). $A$, Ammonium. $B$, Iron. $C$, Sulfate. $D$, Methane.
D' reduction (table 7, fig. 11C). Methane, which is a product of methanogenic degradation, increases from the background well to well MW-10 and then decreases from MW-10 to the wells downgradient from the oil (table 7, fig. 11D).

\section{Sediments}

Biodegradation of hydrocarbons coupled to iron reduction depends on the presence of sediment iron oxyhydroxides in the aquifer $\left(\mathrm{Fe}(\mathrm{OH})_{3}\right.$ in table 1). The reaction produces reduced iron ( $\mathrm{Fe}(\mathrm{II})$ or $\mathrm{Fe}^{+2}$ ), which is mainly retained in the sediments (Baedecker and others, 1993) but also is dissolved in the groundwater (figs. $10 A$ and $11 B$ ). Degradation by iron reduction can be assessed by measuring the depletion of sediment iron oxyhydroxide and the increase in reduced iron in the plume compared to the uncontaminated aquifer.
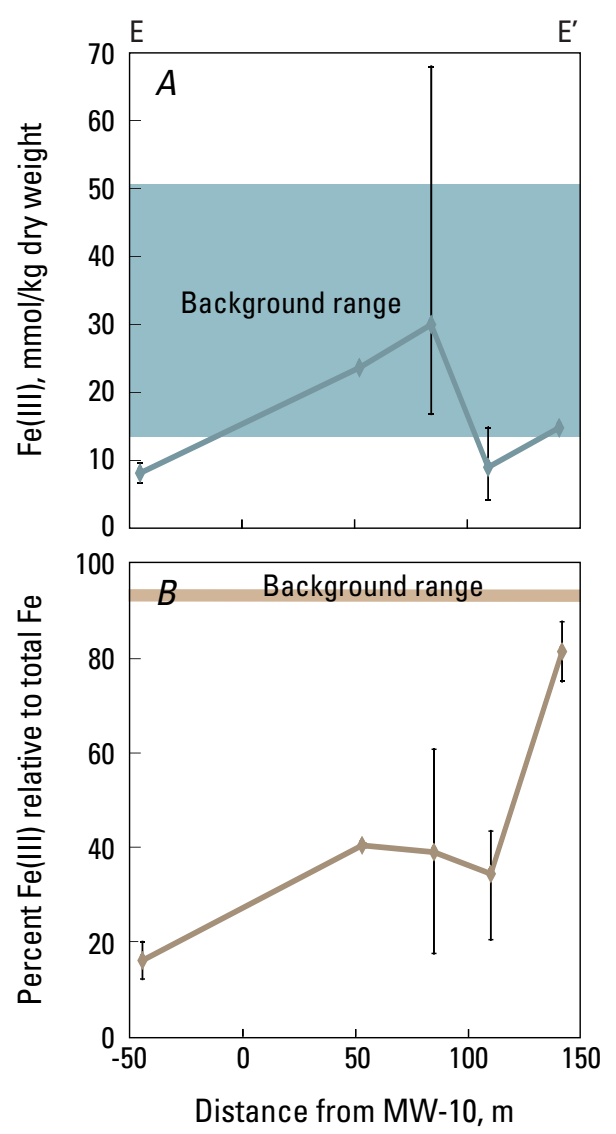

Figure 12. Average oxidized iron $(\mathrm{Fe}(\mathrm{III}))$ measured in sediment cores plotted against distance from well MW-10 along line of section $\mathrm{E}-\mathrm{E}^{\prime}$ in figure $10 B$. Data points, from left to right, are from sediment cores C0811, C0808, C0810, C0804, and C0806. Shaded areas show range of values measured on background sediments. Error bars on points represent minimum and maximum values measured in each core. Distances are in meters $(\mathrm{m})$. $A$, Oxidized iron on sediments (millimoles per kilogram, mmol/kg). $B$, Percent of oxidized iron relative to total iron on sediments. 
Results from the sediment iron analyses are shown in table 8 . Figure $12 A$ shows the concentration of iron oxyhydroxides in the sediment cores along the line of section E-E' in figure $10 B$, and figure $12 B$ shows the percentage of the total extracted iron that is in the oxidized form.

Outside the plume, the iron oxyhydroxide content of the sediments ranges from 14 to $50 \mathrm{mmol} / \mathrm{kg}$ (fig. $12 A$ ), with 94 percent of the total iron in the oxidized form (fig. 12B). The greatest depletion of iron oxyhydroxide occurs in the oil body, where the concentration is $8 \mathrm{mmol} / \mathrm{kg}$ and iron oxyhydroxide makes up 16 percent of the total iron. Farther from the oil, less of the iron oxyhydroxide has been used, and average concentrations range from 9 to $30 \mathrm{mmol} / \mathrm{kg}$, making up 34 to 63 percent of the total iron, respectively.

At $150 \mathrm{~m}$ downgradient from the oil body, the iron oxyhydroxide concentration is $14 \mathrm{mmol} / \mathrm{kg}$, making up 82 percent of the total iron, which is close to the background value. The same pattern, characterized by depletion of iron oxyhydroxide near the plume source, occurs at the Bemidji site. As time progresses, iron oxyhydroxide decreases and reduced iron increases in the anaerobic portion of the plume (Cozzarelli and others, 2001). Near the fringes of the plume, where groundwater containing dissolved reduced iron mixes with water containing dissolved oxygen, significant precipitation of iron oxyhydroxides sometimes occurs. Evidence that this process occurred in the past is apparent at $91 \mathrm{~m}$ downgradient from MW-10 (130 m from the center of the oil body), where the maximum iron oxyhydroxide concentration is significantly greater than the highest background level (fig. 12A). At the Bemidji site a similar buildup of iron oxyhydroxides was found $105 \mathrm{~m}$ downgradient from the center of the oil body (Cozzarelli and others, 2001).

\section{Microbial Populations}

The microbial population data, shown in figures $13 A-D$, support the redox constituent data, indicating that anaerobic degradation occurs in the core of the plume and aerobic degradation occurs at the edges. Populations of microorganisms detected with aerobic growth media are higher than background levels throughout the plume (fig. 13A). These numbers include facultative bacteria that are capable of growing under either anaerobic or aerobic conditions. Their increased numbers in anaerobic portions of the plume reflect the increased numbers of fermenting bacteria compared to outside the plume. Aerobic populations peak at 116 $\mathrm{m}$ downgradient from well MW-10, where dissolved oxygen was measured near the water table in well USGS-3A. Peak aerobe concentrations are expected where there is mixing of reduced carbon from the plume and dissolved oxygen from outside the plume.

The anaerobe population data indicate that biodegradation coupled to iron reduction, sulfate reduction, and methanogenesis are all important, but the relative contribution of each process varies with position in the plume. Peak iron-reducer concentrations of 2,000 times background occur at $91 \mathrm{~m}$ downgradient from well MW-10, corresponding to the location where the highest sediment iron oxyhydroxide concentrations were found (core C0809 adjacent to well cluster USGS-2 in fig. 13B). Iron-reducers within the oil are lower in concentration, but still at least 200 times average background levels. These lower iron-reducer concentrations in the oil body reflect the decreased concentrations of iron oxyhydroxides remaining on the sediments. Concentrations of iron reducers drop to background levels by $146 \mathrm{~m}$ downgradient from well MW-10, reflecting mixing of the plume with oxygenated water and decreasing importance of anaerobic processes.

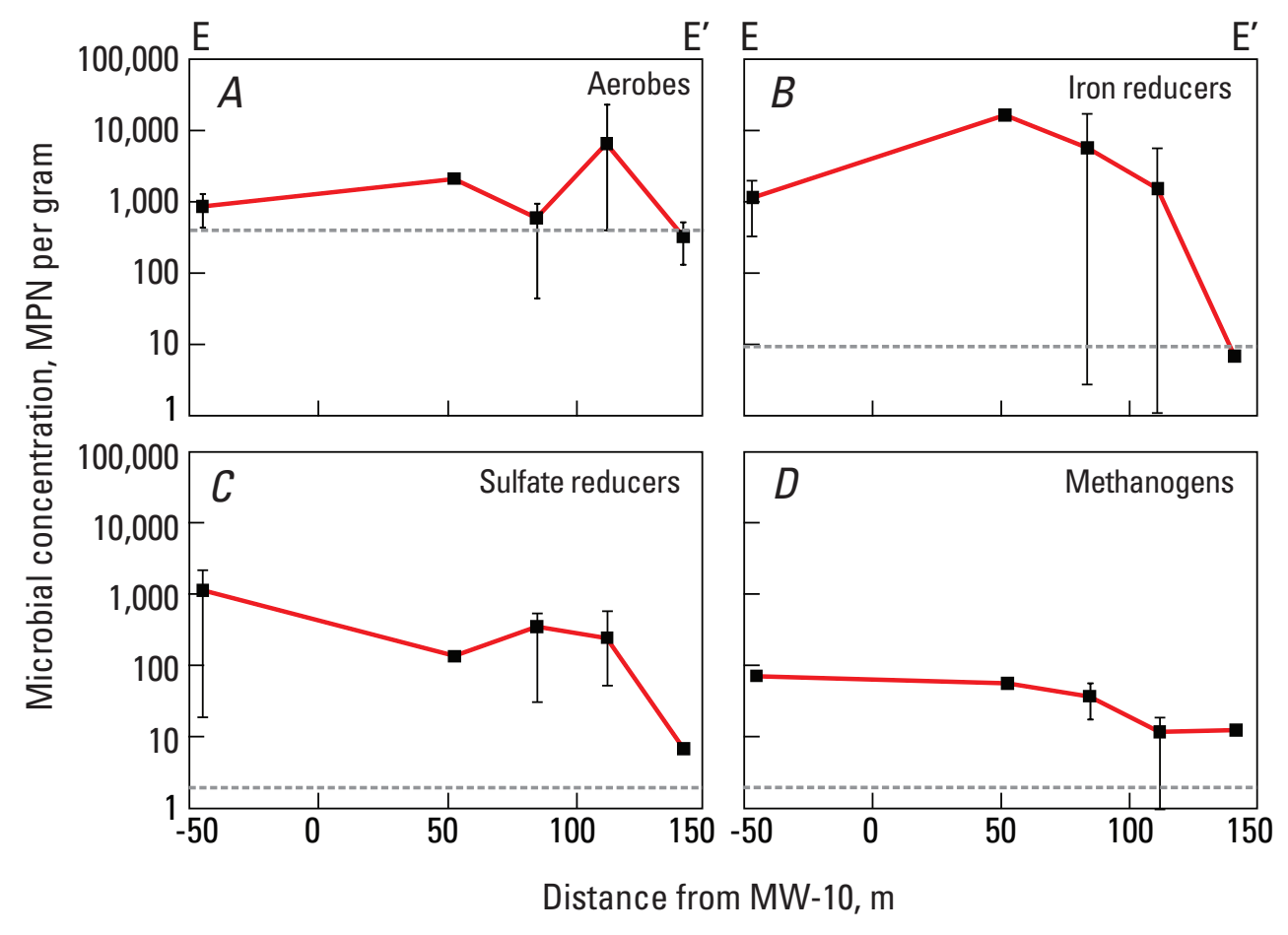

Figure 13. Most probable number (MPN) of four major physiological types of microorganisms along line of section $\mathrm{E}^{\mathrm{E}} \mathrm{E}$ in figure $10 B$. Values given are average for profile, and error bars are maximum and minimum values in each profile. Data points, from left to right, are from sediment cores $\mathrm{C} 0811, \mathrm{C} 0808$, C0810, C0804, and C0806. Distances are in meters $(\mathrm{m})$. Dashed lines indicate numbers for a relatively uncontaminated site outside the plume (Core C0801, fig. 2) for aerobes and iron reducers and indicate detection limits for sulfate reducers and methanogens, which were not found outside the plume. $A$, Aerobes. $B$, Iron reducers. $C$, Sulfate reducers. $D$, Methanogens. 
Sulfate-reducing bacteria were below detection limits $(0.42$ Most Probable Number per gram dry weight sediment, MPN/g, fig. 13C) in background samples (core C0801). Their concentrations peak at more than 2,000 MPN/g within the oil (core C0811), presumably reflecting the continued supply of sulfate in water infiltrating from the surface. Their concentrations are at intermediate levels in the center of the plume (for example, cores C0809 and C0810). Like the iron reducer concentrations, they drop to nearbackground levels by $146 \mathrm{~m}$ downgradient from well MW-10, consistent with a switch from anaerobic to aerobic conditions.

Concentrations of methanogenic microorganisms were also below the detection limit in the background samples (fig. 13D). However, in the oily sediments their concentrations were more than $70 \mathrm{MPN} / \mathrm{g}$, comparable to mixed methanogenic and ironreducing areas of the Bemidji plume (Bekins and others, 1999). The location of the peak concentration of methanogens in the oil is similar to that at the Bemidji site (Bekins and others, 2001). As sediment iron oxyhydroxides become depleted, a microbial consortium performing degradation by fermentation coupled to methanogenesis becomes competitive. Methanogen concentrations remain higher than detection limits throughout the contaminant plume, indicating that reduced conditions have existed for suffi-

Table 8. Results of the sediment iron analyses collected from the Cass Lake site on June 20-23, 2008, and July 18, 2008.

[Core depth intervals are in centimeters $(\mathrm{cm})$ from top of core; see table 3 for depth to top of cores. Locations of cores C0801 through C0811 are shown in figure 2. Iron concentrations are in millimoles per kilogram $(\mathrm{mmol} / \mathrm{kg})$.]

\begin{tabular}{cccc}
\hline Core & Interval, cm & Fe(III), mmol/kg & Fe(II), mmol/kg \\
\hline C0801 & $38-41$ & 13.76 & 0.86 \\
& $64-67$ & 50.72 & 5.22 \\
C0802 & $53-56$ & 13.51 & 17.36 \\
& $64-67$ & 2.91 & 19.96 \\
& $103-106$ & 12.32 & 1.12 \\
C0803 & $19-22$ & 4.39 & 12.91 \\
C0804 & $33-36$ & 4.37 & 15.02 \\
& $64-67$ & 14.91 & 17.88 \\
C0806 & $34-37$ & 14.58 & 4.70 \\
& $84-87$ & 15.26 & 2.10 \\
C0807 & $53-56$ & 7.99 & 12.23 \\
C0808 & $23-27$ & 19.73 & 21.69 \\
C0809 & $53-56$ & 5.29 & 24.70 \\
C0810 & $33-36$ & 67.96 & 107.95 \\
C0811 & $84-87$ & 16.95 & 10.47 \\
& $63-66$ & 9.66 & 38.55 \\
\hline
\end{tabular}

cient time to deplete the aquifer sediment iron oxyhydroxides and allow the methanogen population to become established.

\section{Analysis of Biodegradation Processes}

\section{Comparison of the Bemidji and Cass Lake Sites}

Many aspects of the Cass Lake site are similar to the Bemidji site, suggesting that the biodegradation processes are comparable. At both sites the contaminant is crude oil from the same pipeline and oil field, with an estimated 182,000 L in the aquifer at Cass Lake and 147,000 L at the Bemidji north oil pool (Herkelrath, 1999). Both aquifers are composed of glacial outwash material with silt, sand, and gravel. The 8 to $9 \mathrm{~m}$ depth to the water table at Cass Lake is comparable to the 6 to $8 \mathrm{~m}$ depth at the Bemidji north oil pool (figs. 14 and 15). The groundwater velocity estimate for Cass Lake of $26 \mathrm{~m} / \mathrm{yr}$ is very close to the average velocity for Bemidji of $22 \mathrm{~m} / \mathrm{yr}$. Oxidized iron is the dominant electron acceptor at the Bemidji site, and iron reduction is occurring near the oil body in the Cass Lake plume. Concentrations of methane indicate that methanogenic degradation is occurring near the oil at both sites. Both sites have low concentrations of nitrate in their background groundwater (Baedecker and others, 1993). The background nitrate values are $0.45 \mathrm{mg} / \mathrm{L}$ at Cass Lake and $0.19 \mathrm{mg} / \mathrm{L}$ at Bemidji. Similarly, sulfate background concentrations are also low at both sites, with $1.3 \mathrm{mg} / \mathrm{L}$ at Cass Lake and $2.3 \mathrm{mg} / \mathrm{L}$ at Bemidji (Baedecker and others, 1993).

The geochemistry around the subsurface contamination at the Bemidji north pool site has been categorized into five different zones in the groundwater below the water table (Zones 1 to 5 in fig. 14; Bennett and others, 1993) and three additional chemical zones in the unsaturated sediments above the water table (Zones 6, 7, and 8 in fig. 14; Delin and others, 1998). Zone 1 constitutes the uncontaminated background groundwater with natural background organic matter. Zone 2 underlies the area where the land surface was contaminated by sprayed oil. The groundwater is chemically characterized by decreased oxygen concentrations and contamination with DOC compounds. Zone 3 is the area containing the crude oil floating on the water table and the adjacent portion of the groundwater contaminant plume. The groundwater in Zone 3 is very reduced and anaerobic, with high concentrations of dissolved contaminants and characteristic degradation products including methane and reduced iron. The primary hydrocarbon degradation reactions in Zone 3 occur by reduction of sedimentbound iron oxyhydroxides and by methanogenesis. Zone 4 transitions back to aerobic conditions, with low concentrations of DOC in the aquifer. Zone 5 constitutes the reoxygenated groundwater downgradient from the plume, with slightly elevated concentrations of contaminants.

Zones 6, 7, and 8 are in the unsaturated zone. Zone 6 is uncontaminated and exhibits near atmospheric concentrations of oxygen. Zone 7, a transition zone, is defined by lower concentrations of oxygen compared to background, hydrocarbon concentrations less than $1 \mu \mathrm{g} / \mathrm{L}$, and higher 
concentrations of carbon dioxide and methane compared to background. Zone 8 , immediately adjacent to and within the unsaturated zone oil body, is anaerobic and contains maximum concentrations of more than 10 percent mole fraction carbon dioxide and 20 percent methane (Amos and others, 2005), with hydrocarbons $>1 \mu \mathrm{g} / \mathrm{L}$ (Chaplin and others, 2002).

Figure 15 provides a graphical summary of the geochemical zones at the Cass Lake site for comparison with those at the Bemidji site (fig. 14). The descriptions for Zones $1,3,4$, and 5 for the Bemidji site also apply for the Cass Lake section. Zone 2 is not present at the Cass Lake site because oil was not sprayed onto the land surface there.

A number of important differences also exist between the two sites, providing a potential opportunity to increase understanding of processes that control crude-oil degradation rates in the subsurface. The Bemidji spill occurred in a single incident more than 30 years ago, whereas the Cass Lake spill occurred as an ongoing leak over an unknown period of time ending in early 2002. Because of the large area over which the oil infiltrated the Bemidji aquifer, about 40 percent of the oil is trapped in the unsaturated zone, whereas the small area of the Cass Lake site leak presumably resulted in oil mainly floating at the water table with a minor amount in the unsaturated zone (figs. 14 and 15). Although the climate is identical, the recharge may be much higher through the oil body at the Cass Lake site because the fenced yard of the pumping station is devoid of vegetation and covered with gravel (fig. 15). The kinematic viscosity range of $23-421 \times 10^{-6} \mathrm{~m}^{2} / \mathrm{s}$ (Wenck Associates, 2005) of the Cass Lake site oil is higher than the range measured for the Bemidji oil in 1988-1989 of $10-25 \times 10^{-6} \mathrm{~m}^{2} / \mathrm{s}$ (Landon, 1993). Enhanced recharge through the gravel is expected to slightly increase the oil degradation rates at the Cass Lake site and could result in measurably faster degradation rates compared to the Bemidji site.

The similarity between the Cass Lake and Bemidji benzene degradation rates, redox conditions, and aquifer material all support a hypothesis that the Cass Lake plume is decades old. The presence of culturable methanogens at a location requires that anaerobic conditions be well established and that some iron-oxide depletion has occurred (Bekins and others, 2001). The Cass Lake methanogen data (fig. 13D) and the sediment iron data (fig. 12B) both indicate that anaerobic conditions are well established at the location of USGS-4. In the early years at the Bemidji site, there was an abrupt transition from anaerobic to aerobic conditions downgradient from the oil body, and much of the benzene degradation occurred during this transition (Baedecker and others, 1993; Eganhouse and others, 1993). More recent evidence suggests that benzene at the Bemidji site is degrading under anaerobic conditions in the zone of the plume that has mixed methanogenic and iron-reducing microbial populations (Cozzarelli and others, 2010). The Bemidji plume is now just over 30 years old, and the present pattern of a slow, uniform benzene degradation rate under anaerobic conditions took decades to establish. The Cass Lake plume has a very similar slow benzene degradation rate under anaerobic conditions and thus also can be assumed to be decades old.

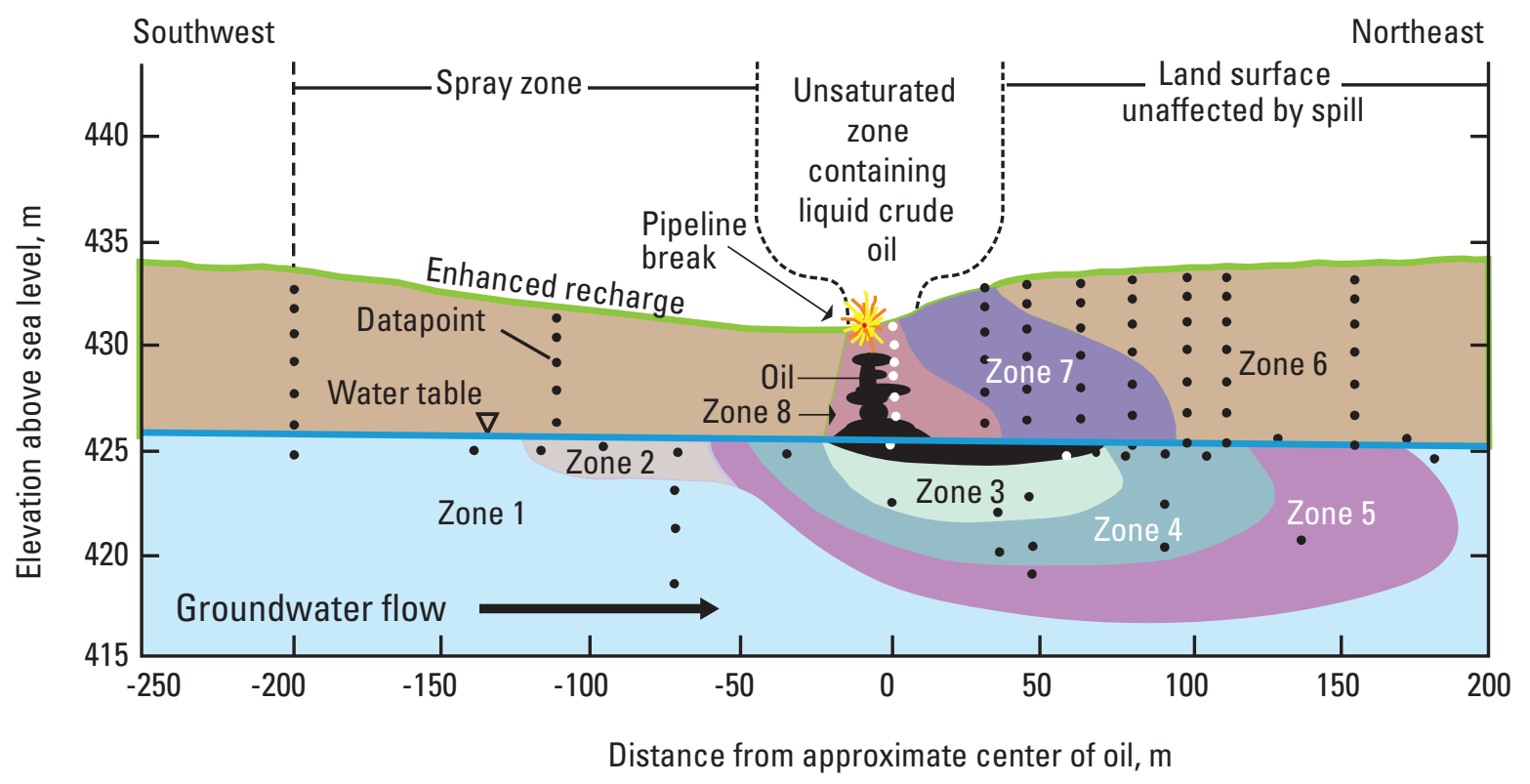

Figure 14. Geochemical zones in the unsaturated and saturated hydrologic zones at the Bemidji crudeoil spill site (modified from Delin and others, 1998). Elevations and distances are in meters (m). Dots represent locations of gas sample ports and monitoring well screens. 


\section{Biodegradation of Oil Body}

\section{Rate}

The highly degraded state of the Cass Lake oil represents one of the significant findings of this study. Although the start date of the Cass Lake leak is unknown, the Bemidji spill is known to have occurred on August 19, 1979. Even though more than 30 years have passed since the Bemidji spill, the spilled oil in some locations is less degraded than the Cass Lake samples. Forensic geochemistry researchers have proposed that unknown oil-spill dates can be inferred from the degradation state of the oil (Christensen and Larsen, 1993). However, work at the Bemidji site has shown that dating of spills based on degradation state is invalid when site conditions differ from those required by the dating method. The method requires the overlying surface to have been paved since the time of the spill, which is rarely the case.
In spite of its uniform age, the Bemidji oil exhibits degradation states ranging from highly degraded with all $n$-alkanes absent to minimally degraded states such as shown in figure 6 and 7. Bekins and others (2005a) showed that the higher degradation rates occur in locations where recharge to groundwater is enhanced by lack of trees and topographic focusing of surface runoff. On the basis of these results, three possible aspects of the Cass Lake spill may contribute to the highly degraded state of the Cass Lake oil: (1) the leak has been active for many years, (2) high recharge rates stimulate degradation, and (3) the leak occurred slowly. These factors are discussed in the following paragraphs.

Although the date that the flange began leaking oil into the subsurface is unknown, the highly degraded nature of the Cass Lake oil suggests the leak was active for decades. A time scale of decades since the onset of the spill is consistent with the highly reduced nature of the plume as indicated by depletion of oxidized iron in the aquifer sediment and by the presence of methanogenic bacteria. In addition, the most-

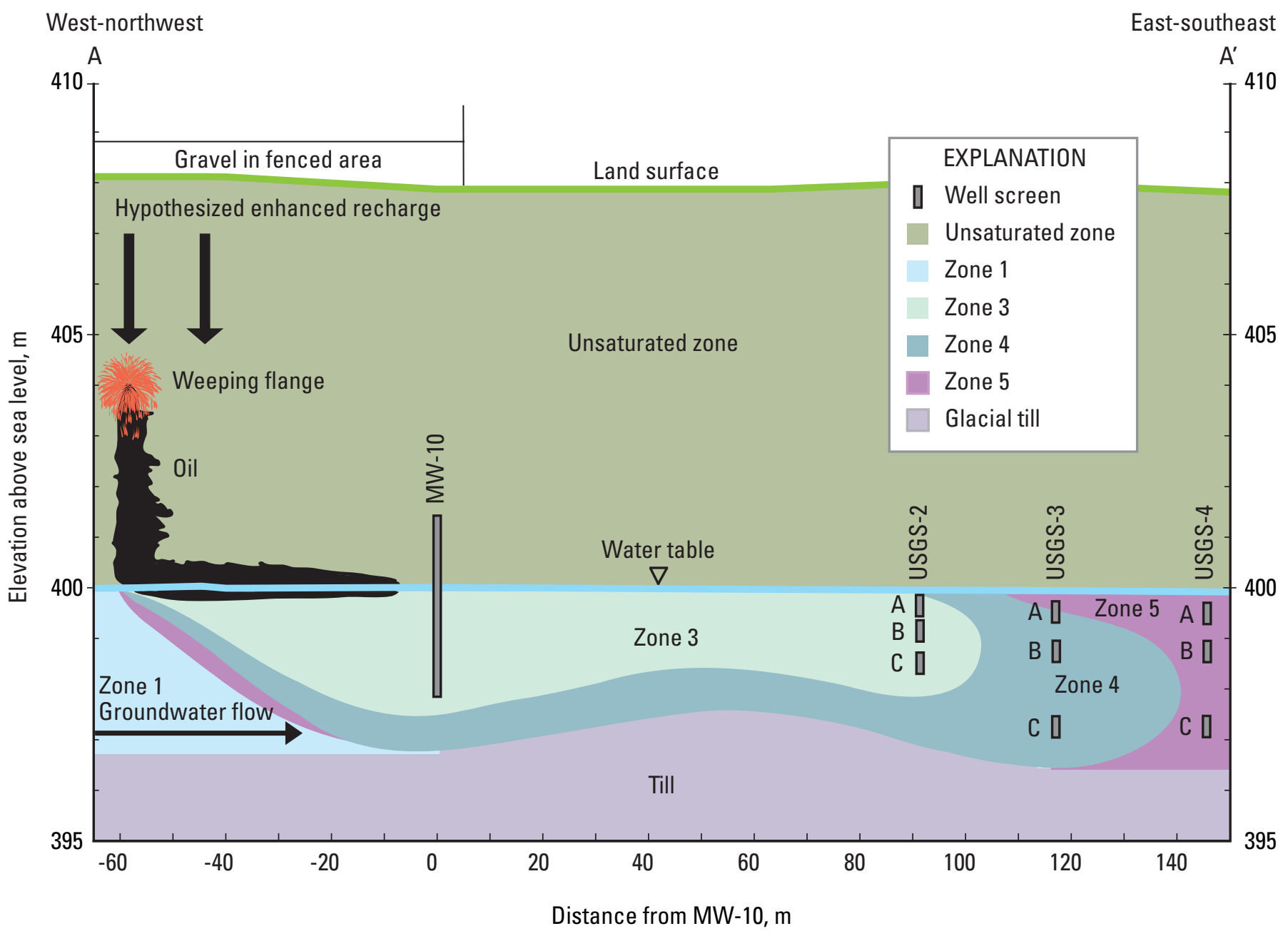

Figure 15. Conceptual model of the oil spill and plume at the Cass Lake site, showing major geochemical zones. Elevations and distances along section A-A' (fig. 2) are in meters (m). 
degradable aromatic hydrocarbons (toluene and $o$-xylene) are now completely absent from the oil. However, even if the leak began when the pumping station opened in 1971, the degree of oil degradation is high compared to the Bemidji spill which occurred just eight years later in 1979.

As noted above, recharge can accelerate degradation of oil (Bekins and others, 2005a). Recharge to groundwater in northern Minnesota occurs primarily in the spring and, to a lesser extent, fall months. In general, the amount of precipitation that enters the groundwater as recharge is decreased by runoff, evaporation, and transpiration by plants. The flat, gravel-covered yard of the South Cass Lake Pumping Station is devoid of vegetation, which likely contributes to rapid infiltration of precipitation and a higher groundwater recharge rate compared to surrounding areas. A high rate of recharge stimulates biodegradation by providing necessary nutrients and moisture to the degrading microbial population and carrying away degradation products. That the Cass Lake oil is so highly degraded compared to the Bemidji oil suggests that enhanced recharge at the site may be an important factor accelerating degradation. Additional information and data analysis on recharge rates at the Cass Lake site are needed in order to verify this hypothesized link between a higher recharge rate and enhanced biodegradation within the gravel-covered yard.

A third hypothesis to explain the highly degraded oil is that the slow nature of the leak allowed aerobic degradation and weathering to take place in the unsaturated zone before the oil reached the water table. Using the estimate of $181,700 \mathrm{~L}$ of oil in the aquifer (Wenck Associates, 2005), it is possible to calculate a minimum leakage rate by assuming the leak began when the oil first entered the pipeline in August 1971. The resulting value is 14.4 liters a day. At this rate, the oil would rapidly migrate to the water table and join the accumulating floating oil body at the water table. Thus, the oil is not expected to be significantly retained in the unsaturated zone before reaching the water table.

\section{Long-Term Fate of Oil}

The progression of biodegradation of oil has been summarized by Peters and others (2005). According to their summary, biodegradation of oil proceeds in a quasi-sequential manner such that easily degradable compounds are lost first, but more resistant classes of compounds begin degrading before complete loss of less-resistant compounds occurs. Data for the Cass Lake site oil samples show near complete depletion of the $n$-alkane fraction, placing the oil in the category of "heavily degraded." The alkylcyclohexanes are only partially degraded, indicting that the oil has not yet reached the category of "severely degraded."

As oil degradation proceeds through higher levels of severity, the soluble fraction decreases to the point where very little dissolution of compounds into the groundwater occurs. Once the oil reaches this degradation state, at an unknown time in the future, the groundwater plume is not expected to pose a risk for further expansion. In the long term, a residual fraction of heavily degraded oil consisting mainly of an unresolvable complex mixture of compounds will remain in the aquifer.

\section{Biodegradation of Groundwater Plume}

\section{Biodegradation Rate}

The attenuation rate of benzene along the main flow path was determined using the maximum concentrations measured at PP-7 and PP-9 (fig. 9A). In this portion of the plume the observed benzene concentrations exceed 1,000 $\mu \mathrm{g} / \mathrm{L}$, so the degradation rate was assumed to be independent of benzene concentration. (This is known as a zero-order rate model.) Using an estimated flow velocity of $26 \mathrm{~m} / \mathrm{yr}$, the resulting benzene attenuation rate is 8 micrograms per liter per day $(\mu \mathrm{g} / \mathrm{L} / \mathrm{d})$. The concentration data for electron acceptors indicate that the main degradation process in the area between PP-7 and PP-9 is iron reduction.

At the Bemidji site, a benzene degradation rate of 8 $\mu \mathrm{g} / \mathrm{L} / \mathrm{d}$ was measured under iron-reducing conditions in an in-place microcosm study conducted during 1998-2001 (Cozzarelli and others, 2010). In 2007, data from the anoxic portion of the Bemidji north pool plume yielded a rate of $4 \mu \mathrm{g} / \mathrm{L} / \mathrm{d}$. The similarity of rates between the two sites suggests that the anaerobic degradation processes are quite similar. However, it is important to note that the estimated rate depends directly on the value assumed for the groundwater flow velocity, which is difficult to measure.

\section{Long-Term Fate of Plume}

The soluble fraction of the oil is the source of dissolved compounds forming the groundwater plume. In 2007, the groundwater plume contained alkylbenzenes and naphthalenes. The oil had very little toluene or $o$-xylene but still contained significant benzene, ethylbenzene, and naphthalenes. The time for complete loss of alkylbenzene and naphthalene compounds from the oil depends on the oil saturation and rate of groundwater flow through the oil body (Essaid and others, 2003). The dissolution rate becomes slower as the concentrations in the oil decrease, resulting in an exponential decay in concentration with time. As concentrations of alkylbenzenes in the oil decrease, the concentration in the groundwater plume will also decrease, and eventually the plume is expected to shrink. The length of time required for the dissolution rate to slow to the point where the plume begins to shrink is a topic of active research at the Bemidji site and cannot be predicted with certainty.

Theoretical calculations predict that the Bemidji plume will grow slowly as iron oxyhydroxides become depleted in the aquifer (Bekins and others, 2005b). However, recent results from the Bemidji site show that calculating the growth rate of the benzene plume requires additional research to better understand two issues. The first issue is the bioavailability of different 
types of iron oxyhydroxides for benzene degradation. Previous results from the Bemidji site indicated that rapid degradation of benzene under iron-reducing conditions required iron oxide to exceed 60 percent of the poorly crystalline iron coatings on the sediments (Bekins and others, 2005a). However, 2007 data from the Bemidji site show that slow degradation of benzene is occurring where iron oxides make up 20 to 30 percent of the poorly crystalline iron. The Cass Lake data show that benzene degradation occurs with 30 to 40 percent iron oxide (figs. $9 A$ and $12 B$ ). It is very encouraging that benzene degradation coupled to iron reduction may occur with lower iron concentrations than previously recognized.

The second issue is that the plume contains many components that can be oxidized by iron-reducing bacteria. For example, methane can be oxidized by iron reduction (Beal and others, 2009), and this process appears to be important at the Bemidji site (Bekins and others, 2008). At the Cass Lake site the maximum concentration of methane occurs in the oil body, and concentrations decrease with distance downgradient from the oil, suggesting that methane is consumed faster than it is produced in the anaerobic plume (fig. 16). A similar pattern of decreasing concentrations with distance is apparent in the ammonium data (fig. 16). Moreover, the high concentration of nitrate at USGS-4C (table 7) may be due to oxidation of ammonium to nitrate. Finally, dissolved organic carbon is transported from the oil body and decreases in concentration, indicating degradation with distance by microorganisms (fig. 16). Altogether, the oxidation of methane, ammonium, and dissolved organic carbon could consume much of the dissolved oxygen and iron oxyhydroxide. A full accounting of all these reactants requires multispecies reactive transport modeling.

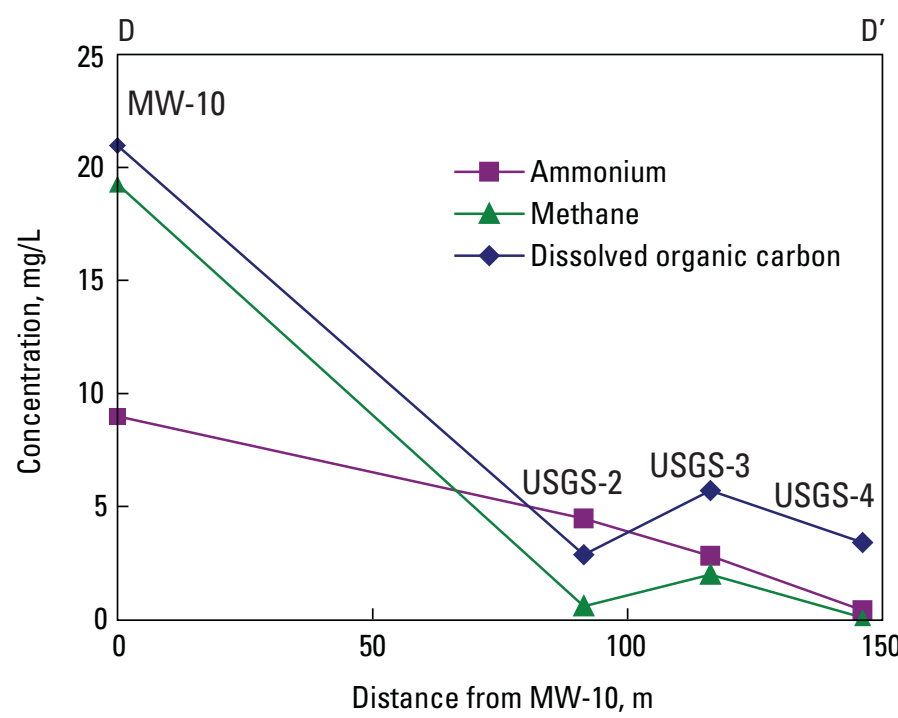

Figure 16. Average concentrations (milligrams per liter, $\mathrm{mg} / \mathrm{L}$ ) of selected constituents at the Case Lake site versus distance (meters, $\mathrm{m}$ ) from well MW-10 along line of section D-D' in figure $10 B$.
Although predicting the timeframe and migration rate of the plume requires more research, natural attenuation is currently protecting the environment and water supplies in the area near the Cass Lake site. For sites contaminated with petroleum hydrocarbons, the biodegradation processes are considered reliable under aerobic and anaerobic conditions (National Research Council, 2000). Therefore, requirements for demonstrating that natural biodegradation is an adequate management strategy for petroleum hydrocarbon plumes are somewhat simpler than for other contaminants. The most important issue is monitoring the plume to show that biodegradation is controlling the growth. The data from USGS-4 show that benzene is present at low concentrations $(<1 \mu \mathrm{g} / \mathrm{L})$, indicating that the location of this well nest can be used to monitor growth of the plume. Figure 17 illustrates the position of the oil body and the dissolved plume with respect to the wetland in the upper reaches of Fox Creek. The Fox Creek wetland, located about $250 \mathrm{~m}$ south of the Cass Lake site, is the nearest receptor (building, surface water, or wells) south of the Cass Lake site. Regarding the threat of contamination of Fox Creek and the wetlands that feed into it: (1) The direction of groundwater flow and therefore plume migration is parallel to Fox Creek rather than toward it. (2) The geochemical and microbial data show the redox conditions are similar to the Bemidji plume, which is decades old. Thus, the Cass Lake Pumping Station oil leak may have been present when the pumping station first began operations in 1971. The evidence that the plume is old implies that its advance rate to date must have been very slow (less than $4 \mathrm{~m}$ per year). Even if the plume doubled in size over the next 40 years (which is unlikely) it would still not impact Fox Creek or the wetlands. However, the well cluster at USGS-4 should be monitored in order to ensure that the current biodegradation processes continue to limit expansion of the plume. In addition, installation of a nest of observation wells in the vicinity of PP-10 would help in this regard.

\section{Conclusions}

A 2-year study by the U. S. Geological Survey of the crude oil spill at the Enbridge South Cass Lake Pumping Station included three-dimensional characterization of the contaminant plume, assessment of the important biodegradation processes, and installation of monitoring wells to assess future changes in the plume. The delineated contaminant plume of greater than $10 \mu \mathrm{g} / \mathrm{L}$ extends approximately $150 \mathrm{~m}$ east of the pumping station fence (fig. 17). The direction of migration is diverted eastward from the generally southeast regional groundwater flow direction, probably because of thinning of the sand-and-gravel aquifer to the south of the Cass Lake site. The dissolved plume is approximately $40 \mathrm{~m}$ across and extends 2 to $3 \mathrm{~m}$ vertically, and the location of maximum concentration becomes deeper with distance. Biodegradation in the oil body and in most of the plume occurs under anaerobic conditions. The important processes are nitrate ammonification, iron reduction, sulfate 
reduction, and methanogenesis. Two samples of oil extracted from sediments and one bailed from a well were all heavily degraded. Sediment iron oxyhydroxide concentrations from sediment samples in the oil body and plume show that iron oxyhydroxides are being utilized by iron-reducing bacteria. The remaining iron oxyhydroxide percentage on the sediments ranges from 15 percent in the oil body, to 34 to 40 percent in the core of the plume, and to 81 percent at the farthest downgradient extent of the plume. The benzene degradation rate is estimated to be $8 \mu \mathrm{g} / \mathrm{L} / \mathrm{d}$, which is comparable to iron-reducing rates at the Bemidji site. The well-established anaerobic microbial populations, degree of iron depletion, and highly degraded state of the oil suggest that the Cass Lake plume has been present for decades.

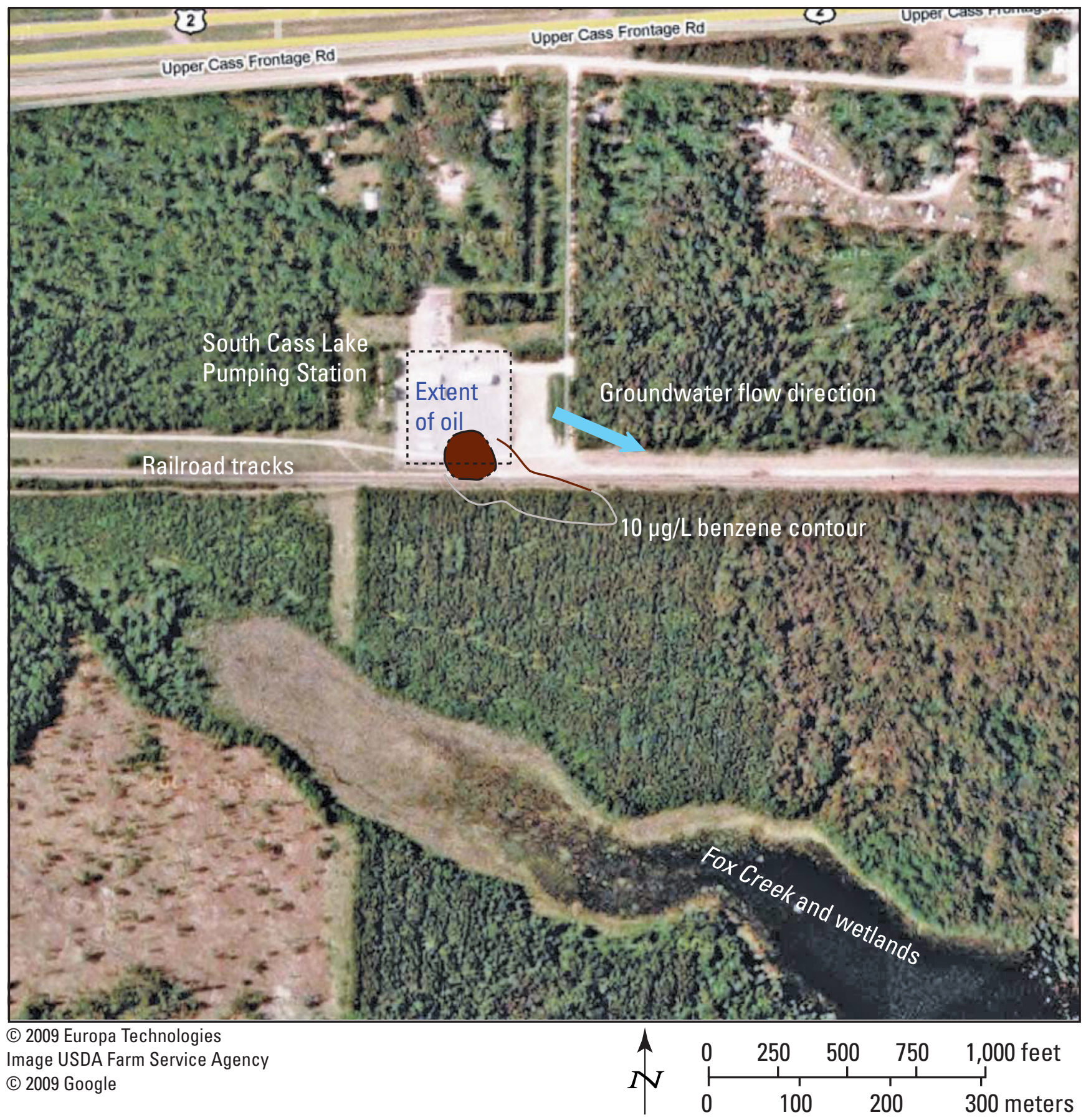

Figure 17. Position of oil body and 10-micrograms-per-liter $(\mu \mathrm{g} / \mathrm{L})$ benzene contour line in the Cass Lake plume with respect to the nearest surface water in the wetland at the headwaters of Fox Creek. 


\section{References}

Alvarez, P.J.J., and Vogel, T.M., 1991, Substrate interactions of benzene, toluene, and para-xylene during microbial degradation by pure cultures and mixed culture aquifer slurries: Applied Environmental Microbiology, v. 57, p. 2981-2985.

Amos, R.T., and Blowes, D.W., 2008, Versatile direct push profiler for the investigation of volatile compounds near the water table: Water Resources Research, v. 44, W00D17, doi:10.1029/2008WR006936.

Baedecker, M.J., and Cozzarelli, I.M., 1992, The determination and fate of unstable constituents in contaminated groundwater, in Lesage, S., and Jackson, R., eds., Groundwater quality and analysis at hazardous waste sites: New York, Marcel Dekker, Inc., p. 425-461.

Baedecker, M.J., Cozzarelli, I.M., Siegel, D.I., Bennett, P.C., and Eganhouse, R.P., 1993, Crude oil in a shallow sand and gravel aquifer. III. Biogeochemical reactions and mass balance modeling in anoxic groundwater: Applied Geochemistry, v. 8 , no. 6 , p. $569-586$.

Beal, E.J., House, C.H., and Orphan, V.J., 2009, Manganeseand iron-dependent marine methane oxidation: Science, v. 325, p. 184-187.

Bekins, B.A., Godsy, E.M., and Warren, E., 1999, Distribution of microbial physiologic types in an aquifer contaminated by crude oil: Microbial Ecology, v. 37, p. 263-275.

Bekins, B.A., Cozzarelli, I.M., Godsy, E.M., Warren, E., Essaid, H.I., and Tuccillo, M.E., 2001, Progression of natural attenuation processes at a crude oil site. II. Controls on spatial distribution of microbial populations: Journal of Contaminant Hydrology, v. 53, p. 387-406.

Bekins, B.A., Hostettler, F.D., Herkelrath, W.N., Delin, G.N., Warren, E., and Essaid, H.I., 2005a, Progression of methanogenic degradation of crude oil in the subsurface: Environmental Geosciences, v. 3, p. 139-152.

Bekins, B.A., Cozzarelli, I.M., and Curtis, G.P., 2005b, A simple method for calculating growth rates of petroleum hydrocarbon plumes: Ground Water, v. 43, no. 6, p. 817-826.

Bekins, B.A., Amos, R.T., Cozzarelli, I.M., Voytek, M.A., Kirshtein, J., Jones, E.J., and Delin, G.N., 2008, Evidence for anaerobic methane oxidation under iron-reducing conditions in a crude-oil contaminated aquifer [abs.]: Eos (American Geophysical Union Transactions), v. 89, no. 53, Fall meeting supplement, abs. B11B-0352.

Bennett, P.C., Siegel, D.I., Baedecker, M.J., and Hult, M.F., 1993, Crude oil in a shallow sand and gravel aquifer. I. Hydrogeology and inorganic geochemistry: Applied Geochemistry, v. 8, p. 529-549.
Chaplin, B.P., Delin, G.N., Baker, R.J., and Lahvis, M.A., 2002, Long-term evolution of biodegradation and volatilization rates in a crude oil-contaminated aquifer: Bioremediation Journal, v. 6, p. 237-255.

Christensen, L.B., and Larsen, T.H., 1993, Method for determining the age of diesel oil spills in the soil: Ground Water Monitoring and Remediation, v. 13, p. 142-149.

Clark, I.D., and Fritz, P., 1997, Environmental isotopes in hydrogeology: New York, CRC Press, 352 p.

Cozzarelli, I.M., and Baehr, A.L., 2003, Volatile fuel hydrocarbons and MTBE in the environment, in Lollar, B.S., ed., Environmental geochemistry: Elsevier, Treatise on Geochemistry, v. 9, p. 433-474.

Cozzarelli, I.M, Eganhouse, R.P., and Baedecker, M.J., 1990, Transformation of monoaromatic hydrocarbons to organic acids in anoxic groundwater environment: Environmental Geology and Water Sciences, v. 16, p. 135-141.

Cozzarelli, I.M., Bekins, B.A., Baedecker, M.J., Aiken, G.R., Eganhouse, R.P., and Tuccillo, M.E., 2001, Progression of natural attenuation processes at a crude-oil spill site. I. Geochemical evolution of the plume: Journal of Contaminant Hydrology, v. 53, p. 369-385.

Cozzarelli, I.M., Bekins, B.A., Eganhouse, R.P., Warren, E., and Essaid, H.I., 2010, In situ measurements of volatile aromatic hydrocarbon biodegradation rates in groundwater: Journal of Contaminant Hydrology, v. 111, p. 48-64.

Delin, G.N., Essaid, H.I., Cozzarelli, I.M., Lahvis, M.H., and Bekins, B.A., 1998, Groundwater contamination by crude oil near Bemidji, Minnesota: U.S. Geological Survey Fact Sheet 084-98, 4 p.

Dillard, L.A., Essaid, H.I., and Herkelrath, W.N., 1997, Multiphase flow modeling of a crude-oil spill site with a bimodal permeability distribution: Water Resources Research, v. 33, no. 7 , p. $1617-1632$

Eganhouse, R.P., Baedecker, M.J., Cozzarelli, I.M., Aiken, G.R., Thorn, K.A., and Dorsey, T.F., 1993, Crude oil in a shallow sand and gravel aquifer. II. Organic geochemistry: Applied Geochemistry, v. 8, no. 6, p. 551-567.

Eganhouse, R.P., Dorsey, T.F., Phinney, C.S., and Westcott, A.M., 1996, Processes affecting the fate of monoaromatic hydrocarbons in an aquifer contaminated by crude oil: Environmental Science and Technology, v. 30, p. 3304-3313.

Essaid, H.I., Bekins, B.A., Godsy, E.M., Warren, E., Baedecker, M.J., and Cozzarelli, I.M., 1995, Simulation of aerobic and anaerobic biodegradation processes at a crudeoil spill site: Water Resources Research, v. 31, no. 12, p. 3309-3327. 
Essaid, H.I., Cozzarelli, I.M., Eganhouse, R.P., Herkelrath, W.N., Bekins, B.A., and Delin, G.N., 2003, Inverse modeling of BTEX dissolution and biodegradation at the Bemidji, MN crude-oil spill site: Journal of Contaminant Hydrology, v. 67 , p. $269-299$.

Gibbs, M.M., 1979, A simple method for the rapid determination of iron in natural waters: Water Research, v. 13, p. 295-297.

Hazen, A., 1892, Some physical properties of sands and gravels, with special reference to their use in filtration: Massachusetts State Board of Health, 24th Annual Report, Public Document no. 34, p. 539-556.

Herkelrath, W.N., 1999, Impacts of remediation at the Bemidji oil-spill site, in Morganwalp, D.W., and Buxton, H.T., eds., U.S. Geological Survey toxic substances hydrology program-Proceedings of the Technical Meeting, Charleston, South Carolina, March 8-12, 1999. Volume 3 of 3. Subsurface contamination from point sources: U.S. Geological Survey Water-Resources Investigations Report 99-4018C, p. 195-200.

Herkelrath, W.N., Delin, G.N., and Cozzarelli, I.M., 2008, Using peristaltic bailing to obtain ground water samples in push probe profiling of a subsurface BTEX plume: Geological Society of America Abstracts with Programs, v. 40, no. 6, p. 343.

Hostettler, F.D., Rosenbauer, R.J., Lorenson, T.D., and Dougherty, J., 2004, Geochemical characterization of tarballs on beaches along the California coast. Part 1. Shallow seepage impacting the Santa Barbara Channel Islands, Santa Cruz, Santa Rosa, and San Miguel: Organic Geochemistry, v. 35, no. 6, p. 725-746.

Hostettler, F.D., Wang, Y., Huang, Y., Cao, W., Bekins, B.A., Rostad, C.E., Kulpa, C.F., and Laursen, A., 2007, Forensic fingerprinting of oil-spill hydrocarbons in a methanogenic environment-Mandan, ND and Bemidji, MN: Environmental Forensics, v. 8, p. 139-153.

Kanivetsky, R., 1979, Hydrogeologic map of Minnesota, Quaternary hydrogeology: Minnesota Geological Survey, scale 1:500000.

Landon, M.K., 1993, Investigation of mass loss based on evolution of composition and physical properties of spilled crude oil contaminating a shallow outwash aquifer: Minneapolis, University of Minnesota, M.S. thesis.

Lohman, S.W., 1972, Ground-water hydraulics: U.S. Geological Survey Professional Paper 708, 70 p.

Lovley, D.R., and Phillips, E.J.P., 1986, Organic matter mineralization with reduction of ferric iron in anaerobic sediments: Applied and Environmental Microbiology, v. 51, p. 683-689.
Meckenstock, R.U., Annweiler, E., Michaelis, W., Richnow, H.H., and Schink, B., 2000, Anaerobic naphthalene degradation by a sulfate-reducing enrichment culture: Applied and Environmental Microbiology, v. 66, p. 2743-2747.

Meyall, G.G., and Meyall, E., 1970, Theory and practice in experimental bacteriology: New York, Cambridge University Press, 288 p.

Mihelcic, J.R., and Luthy, R.G., 1988, Degradation of polycyclic aromatic hydrocarbons compounds under various redox conditions in soil-water systems: Applied and Environmental Microbiology, v. 54, p. 1182-1187.

Murphy, F., and Herkelrath, W.N., 1996, A sample-freezing drive shoe for a wire line piston core sampler: Ground Water Monitoring and Remediation, v. 16, no. 3, p. 86-90.

National Research Council, 1993, In-situ bioremediation: Washington, D.C., National Academy Press, p. 65-80.

National Research Council, 2000, Natural attenuation for groundwater remediation: Washington, D.C., National Academy Press, 292 p.

Natural Resources Engineering Company, 2003, South Cass Lake Pumping Station remedial investigation report (MPCA spill \#54827): Cass Lake, Minnesota, status report October 2003, 13 p.

Natural Resources Engineering Company, 2004, South Cass Lake Pumping Station remedial investigation report (MPCA Spill \# 54827): Cass Lake, Minnesota, status report May 21, 2004, 13 p.

Natural Resources Engineering Company, 2009, Status update_-groundwater monitoring report; Enbridge's South Cass Lake Pumping Station: Cass Lake, Minnesota, January 15, 2009, 47 p.

Perry, J.J., 1984, Microbial metabolism of cyclic alkanes, in Atlas, P.M., ed., Petroleum microbiology: New York, Macmillan, p. 61-67.

Peters, K.E., Walters, C.C., and Moldowan, J.M., 2005, The biomarker guide; 2nd Edition, biomarkers and isotopes in the environment and human history: Cambridge, U.K., Cambridge University Press, 1155 p.

Peters, K.E., Hostettler, F.D., Lorenson, T.D., and Rosenbauer, R.J., 2008, Families of Miocene Monterey crude oil, seep, and tarball samples, coastal California: American Association of Petroleum Geologists Bulletin, v. 92, no. 9, p. 1131-1152.

Radtke, D.B., White, A.F., Davis, J.V., and Wilde, F.D., 1998, Dissolved oxygen (version dated April 1998): U.S. Geological Survey Techniques of Water-Resources Investigations, book 9, chap. A6, section 6.2. 
Rice, D.W., Grose, R.D., Michaelsen, J.C., Dooher, B.P., MacQueen, D.H., Cullen, S.J., Kastenberg, W.E., Everett, L.G., and Marino, M.A., 1995, California leaking underground fuel tank (LUFT) historical case analyses: Lawrence Livermore National Laboratory, Report UCRL-AR-122207, 65 p.

Solano-Serena, F., Marchal, R., Ropars, M., Lebeault, J.-M., and Vandercasteele, J.-P., 1999, Biodegradation of gasoline; kinetics, mass balance and fate of individual hydrocarbons: Journal of Applied Microbiology, v. 86, p. 1008-1016.

Stark, J.R., Busch, J.P., and Deters, M.H., 1991, Hydrogeology and water quality of glacial-drift aquifers in the BemidjiBagley area, Beltrami, Clearwater, Cass, and Hubbard Counties, Minnesota: U.S. Geological Survey WaterResources Investigations Report 89-4136, 135 p.

Warren, E., Prudic, D.E., and Godsy, E.M., 2006, Changes in microbial activity, in Green, J.M., ed., The effectiveness of Cattlemans detention basin, South Lake Tahoe, California: U.S. Geological Survey Scientific Investigations Report 2006-5259, p. 37-48.
Wiedemeier, T., Wilson, J.T., Kampbell, D.H., Miller, R.N., and Hansen, J.E., 1995, Technical protocol for implementing intrinsic remediation with long-term monitoring for natural attenuation of fuel contamination dissolved in groundwater, volume I: San Antonio, Texas, Air Force Center for Environmental Excellence, Technology Transfer Division, Brooks Air Force Base Report A324248, 295 p.

Wenck Associates, 2005, Preliminary feasibility study-South Cass Lake Site, July 2005, 19 p.

Wenck Associates, 2006, Annual (2005) progress report, Enbridge South Cass Lake leak Site, March 2006, 13 p.

Wolf, S.H., Celia, M.A., and Hess, K.M., 1991, Evaluation of hydraulic conductivities calculated from multiportparameter measurements: Ground Water, v. 29, no. 4, p. 516-525.

Produced in the Western Region, Menlo Park, California

Manuscript approved for publication, April 14, 2010

Text edited by Peter H. Stauffer

Layout and design by Jeanne S. DiLeo 
$\frac{k}{20}$

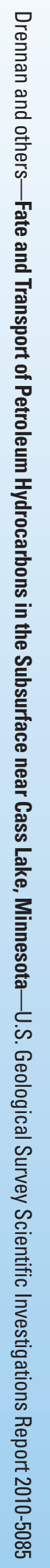

